\title{
Fair Use and Beyond: The Status of Copyright Limitations and Exceptions in the Commonwealth of Independent States
}

\author{
Janice T. Pilch
}

\begin{abstract}
Fair-use and other free-use limitations and exceptions in national copyright laws maintain a balance between the individual interests of creators of works and other copyright holders, and the public interest in fostering a culturally productive exchange of information and ideas. The status of fair use and free use has come into question in recent years, in part by the rapid pace of technological change, which has led to laws favoring new modes of information management. This article discusses fair-use and other copyright limitations and exceptions in an international context and their origins in international conventions, treaties, and agreements. It then offers a comparative analysis of the limitations and exceptions found in the current copyright laws of the twelve nations comprising the Commonwealth of Independent States (CIS), highlighting the range of limitations and exceptions found in the CIS statutes and the differences among the laws of those nations. In the current climate of change in global copyright legislation, this article provides broad perspective in an area that is of increasing relevance to the aims of academic and research libraries internationally.
\end{abstract}

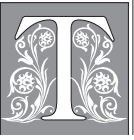

he status of fair use is a subject of increasing concern in libraries, archives, and educational institutions that have long relied on limitations and exceptions in copyright laws to carry out essential services in support of research and education. In the United States, fair use makes it possible for individuals to quote from, or reproduce, copyrighted materials without seeking permission from the copyright holder. It allows instructors to photocopy excerpts from books, journals, newspapers, and other works for classroom teaching, to quote from works in their publications, and to place course materials on reserve in print and electronically. The fair use doctrine makes it possible for students to photocopy passages from copyrighted materials and to quote from others' writings in their own written work. Further exceptions in the

Janice T. Pilch is Slavic and East European Technical Services Librarian and Assistant Professor of Library Administration at the University of Illinois at Urbana-Champaign; e-mail: pilch@uiuc.edu. 
1976 U.S. Copyright Act allow research libraries and archives to reproduce copyrighted books, journals, and newspapers that have been lost or stolen from their collections or that have become damaged or obsolete, and to lend materials on-site and through interlibrary loan.

In the United States, the judicial doctrine of fair use, having originated in a decision by Justice Story in the 1841 case Folsom v. Marsh, and having first been articulated in the 1869 case Lawrence v. Dana, became part of U.S. law in the 1976 U.S. Copyright Act. ${ }^{1,2}$ The earlier copyright law, the 1909 U.S. Copyright Act, did not contain a provision for fair use. In response to issues facing research libraries in connection with the growing use of methods of photographic reproduction, a "Gentlemen's Agreement" between the Joint Committee on Materials for Research and the National Association of Book Publishers was reached in 1935 and served as an unofficial guideline for libraries, archives, and other institutions with respect to the reproduction of printed material until the fair-use doctrine was incorporated into the U.S. Copyright Act of $1976 .{ }^{3}$ The fair-use doctrine is a judicial tool for maintaining a balance between the interests of the creators of works in seeking reward for their creative activity and the public interest in having works freely available for use. Put in broader terms, it mediates between individual and social interests.

As the digital age progresses, we face a situation in which a large number of copyrighted works will be created and stored almost exclusively in digital format. With the advent of intellectual property laws developed to control the use of digital material, in particular with the introduction in the United States of the Digital Millennium Copyright Act (DMCA) in 1998, implementing the two 1996 treaties administered by the
World Intellectual Property Organization (WIPO), the WIPO Copyright Treaty and the WIPO Performances and Phonograms Treaty, fair use is being compromised with respect to copyrighted works stored in a digital medium. Under the provisions of the 1976 Copyright Act, as amended by the DMCA, fair use has already been overridden as a defense to copyright violation for reproduction of a digitally stored and encrypted work. Along with this, the growth of licensing threatens to erode the validity of fair use as the business sector defines the terms of information management in areas such as electronic books, serial aggregations, and other digitized and born-digital materials. At the outer edges of the current debate on fair use, arguments are advanced that whereas the effects on copyright holders of fair-use or private-use exceptions might have been minimal in the past, current technology may make them unacceptable and no longer compatible with the Berne Convention. ${ }^{4}$ Technology itself is offered as a means of bypassing copyright because digital rights management systems are considered options for controlling copyright infringement by eliminating the decisions involved in applying the fair-use doctrine.

The library and educational communities are working to maintain and expand awareness of the importance of fair use to the progress of learning and to cultural advancement and of its global significance in the digital and networked environment. Efforts to assess the impact of technological change on fair use and to defend its role in the digital environment are escalating, and it is as important as ever to understand fully what fair use is and how it relates to other types of limitations and exceptions in copyright law. In the ongoing international discussion of exceptions to copyright that have not merely benefited, but indeed have 
made possible, research and educational pursuits, it is helpful to gain perspective on the relative strength of fair use and its equivalents in the statutes of other nations. A comparative analysis lends perspective in an area that has truly become an international concern.

This article is an attempt to show how copyright limitations and exceptions fare in the nations that currently make up the Commonwealth of Independent States (CIS). For the better part of the twentieth century, these former Communist entities placed heavy emphasis on social and public interests at the expense of private interests, an emphasis that was reflected in the copyright law of the former Soviet Union. Since the demise of the Soviet Union, all of these nations have enacted new national copyright laws, or in the case of Turkmenistan amended existing laws, and many of the new laws have undergone amendment since they came into being. ${ }^{5}$ A comparative analysis highlights the range of limitations and exceptions to copyright found in the statutes of the CIS nations and also offers a view of the differences among the laws of those nations. This study is intended to complement other recent articles covering the more practical aspects of copyright for materials originating in CIS nations and being used in the United States in the library and educational spheres. ${ }^{6}$ Its methodology is analytical rather than practical, with the primary aim of illuminating the issue of fair and free use from a comparative perspective. Practical applications of this analysis are summarized at the end of the study.

\section{Fair Use in an International Context}

A preliminary note on terminology is in order to clarify how the fair-use doctrine relates to other exceptions in the U.S. copyright law and how it fits within the international scheme of copyright limitations and exceptions. The phrase "fair use" is most often associated with an American concept that evolved as a judicial doctrine and that now has a statutory basis in Section 107 of the 1976 U.S. Copyright Act as a valid defense to copyright violation. The phrase "fair dealing" is used in the United Kingdom and other common-law nations deriving their copyright laws from English law. Fair use and fair dealing have their origins in common-law doctrine as a defense of the use of copyrighted material that would otherwise be infringing and are rooted in the Anglo-American common-law tradition of case-by-case adjudication. The fairuse provision does not provide a defined list of uses deemed to be fair. Rather, it requires an open-ended equitable balancing inquiry that assesses the use relative to several factors. The American fair-use doctrine takes a considerably broader approach than even the fair-dealing provisions of other common-law nations.

Nations of the civil law tradition, associated with continental Europe, do not have an expansive or flexible doctrine equivalent to the U.S. fair-use provision. The European solution to the problem of fair use involves a number of specific, discrete limitations or exceptions. In the civil law nations, the notions of fair use and fair dealing are not present as doctrines as such. However, the concept of free use is indeed present. Free use is a more general concept, characterizing a type of limitation that exists in copyright laws of both civil and common-law tradition, involving use of a work that does not require payment or authorization, subject to certain conditions, primarily because the use is informatory or advances educational, scientific, or cultural development. ${ }^{7}$ Fair use and fair dealing are approaches in the common-law tradition for providing free use. Free use is a category of limitation or exception. 
The term "fair practice" also occurs in discussions of copyright limitations and exceptions. It appears in the Berne Convention in two contexts, in connection with the exception for quotations in Article 10(1) and the exception for illustration in teaching in Article 10(2), as a term denoting an objective assessment of fairness, developed by courts in each country, for such free use of works. ${ }^{8}$ The above terms are often used in ways that can be confusing to nonspecialists.

The CIS nations have constructed their new copyright laws in the civil law tradition, which was prevalent in much of the territory comprising these nations before the Communist era. The very use of the term "author's right" in CIS laws, as opposed to "copyright," is an indication that the copyright laws of these nations are associated with the continental European system of author's right (droit d'auteur), or the civil law tradition. In CIS nations, the phrase "free use" is commonly used in provisions that deal with specific limitations or exceptions to the exclusive rights of authors that do not require remuneration or authorization, but none of the nations has an open-ended equivalent of the American fair-use doctrine. A number of exceptions in the CIS laws allow for the free use of material for specific purposes and under specific conditions.

Even in the United States, the phrase "fair use" is tied to the provisions stipulated in Section 107 of the 1976 Copyright Act but is often confused with other provisions that limit the exclusive rights of authors and copyright holders, such as limitations on exclusive rights for libraries and archives stipulated in Section 108, or the limitation concerning transfer of a particular copy of a work or a phonorecord, commonly known as the "firstsale" doctrine, in Section 109, or even the provision for use of works as classroom illustrations in Section 110. There are now fifteen limitations and exceptions to the exclusive rights of authors and other copyright holders in the U.S. copyright law in addition to the fair-use doctrine. They are found in Sections 107-122 of the 1976 Copyright Act. It bears repeating that fair use is but one limitation.

The fair-use doctrine was meant to be ambiguous as well as flexible, unlike the other specific limitations and exceptions found in U.S. law or laws of other nations. Its open formulation was intentional on the part of Congress so that the doctrine would be adaptable to new forms of technology over time. The House Committee Report on the 1976 Copyright Bill that became Section 107 reads:

The statement of the fair use doctrine in section 107 offers some guidance to users in determining when the principles of the doctrine apply. However, the endless variety of situations and combinations of circumstances that can arise in particular cases precludes the formulation of exact rules in the statute. The bill endorses the purpose and general scope of the judicial doctrine of fair use, but there is no disposition to freeze the doctrine in the statute, especially during a period of rapid technological change. Beyond a very broad statutory explanation of what fair use is and some of the criteria applicable to it, the courts must be free to adapt the doctrine to particular situations on a case-bycase basis. Section 107 is intended to restate the present judicial doctrine of fair use, not to change, narrow, or enlarge it in any way. ${ }^{9}$

Section 107 establishes that certain uses of copyrighted material are not infringing and provides a nonexhaustive list of such noninfringing uses: criticism, comment, 
news reporting, teaching, (including multiple copies for classroom use), scholarship, and research. It then provides the well-known list of four factors to be used in a determination of whether a particular use is a fair use:

1. the purpose and character of the use, including whether such use is of a commercial nature or is for nonprofit educational purposes;

2. the nature of the copyrighted work;

3. the amount and substantiality of the portion used in relation to the copyrighted work as a whole;

4. the effect of the use upon the potential market for or value of the copyrighted work.

It also provides for the noninfringing use of unpublished works: "The fact that a work is unpublished shall not itself bar a finding of fair use if such finding is made upon consideration of all the above factors."

Section 107 has been described as a "broad, largely judicially created doctrine that defies a simple definition or description.... Reduced to its most basic definition, the fair use exception permits what would otherwise be an infringing use of a work because allowing the use will result in a greater public benefit than denying it." ${ }^{10}$ One commentator called Section 107 the "adjustable tool" for judicial balancing of copyright, while labeling categorical exemptions "precision tools" for fine-tuning the copyright balance legislatively. ${ }^{11}$ But even as it is regarded as a cornerstone of free use of information, the concept of fair use is not without its critics. The doctrine is considered by some to be troublesome, and it has been criticized for its ambiguity with respect to the other copyright limitations and exceptions in the 1976 U.S. Copyright Act:

Because $\S 107$ is followed by fourteen other sections providing cat- egorical exceptions in considerable detail, it is tempting to conclude that the exceptions in $\$ 107$ are not categorical and are reserved for special circumstances. But the references in $\S 107$, even if only exemplary, are too clearly to the contrary. Thus one is left with categorical exceptions and the list of four factors to consider. Are the uses mentioned in the statute, then, presumptively fair use, exceptions to the general copyright rule, unless so-called "factor analysis" indicates special circumstances warranting an exception to the exception, bringing them back within the rule? Or do those uses have to pass through the mesh of factor analysis on the same terms as other uses, with perhaps an extra cheer if they succeed? Who knows?"12

The concept of fair use in U.S. law, as codified in Section 107 of the Copyright Act of 1976, is far broader than the limitations on copyright that have been adopted in other nations. Fair use is not an international standard. Such a standard does not exist, although there are suggestions that a comprehensive interpretation of existing national and international legislation might make it possible to develop an international law of fair use. ${ }^{13}$ Fair use captures a great deal of attention in library and legal literature. Its context in relation to other limitations and exceptions in U.S. copyright law draws somewhat less attention, and the comparative view of limitations and exceptions in other countries is even less studied. A direct comparison of U.S. and CIS exceptions would be difficult within the scope of this article. U.S. exceptions are generally longer, convoluted, and more technical than those of the CIS and exhibit an indistinct relationship to Berne provisions in syntax and structure. Because CIS laws are the emphasis of this 
article, the following discussion focuses on international copyright limitations and exceptions.

\section{Limitations and Exceptions to Exclusive Rights of Copyright Holders in International Conventions, Treaties, and Agreements}

Limitations and exceptions may be included in international, regional, and national legislation, and they may vary widely from country to country. As is well known, the foundation of international copyright is the Berne Convention, established in 1886. The current version of the Berne Convention, the Paris Revision, dates from July 24, 1971, and entered into force on October 10, 1974. The United States became a party to this convention in 1989. The USSR was making plans to join and was revising its federal copyright law to implement the Berne Convention but dissolved before that happened. All of the CIS nations except Turkmenistan and Uzbekistan joined the Berne Convention after the fall of the Soviet Union in 1991. Other international treaties, conventions, and multilateral trade agreements are developed in relation to Berne, to expand its application, clarify its meaning, or apply it to new technologies. Within the context of this discussion of copyright limitations and exceptions in the laws of CIS nations, it is worth keeping in mind that Berne was in place long before the U.S. doctrine of fair use was legally recognized and that it is an instrument based on the continental perspective.

The Berne Convention contains a number of articles outlining specific restrictions to rights of copyright holders for implementation in member nations. Only two of these are actually mandatory; the others are left for member countries to introduce in their domestic legislation as they see fit. Moreover, the Berne Conven-

\begin{tabular}{|c|c|c|c|c|c|}
\hline \multicolumn{6}{|c|}{$\begin{array}{c}\text { TABLE } 1 \\
\text { Membership of CIS Nations in International Copyright Conventions, } \\
\text { Treaties, and Agreements Listing Year of Entry }\end{array}$} \\
\hline & $\begin{array}{c}\text { Berne } \\
\text { Convention }\end{array}$ & $\begin{array}{c}\text { Rome } \\
\text { Convention }\end{array}$ & $\begin{array}{l}\text { WIPO } \\
\text { Copyright } \\
\text { Treaty }\end{array}$ & $\begin{array}{c}\text { WIPO } \\
\text { Performances } \\
\text { and Phonograms } \\
\text { Treaty }\end{array}$ & $\begin{array}{c}\text { TRIPS } \\
\text { Agreement }\end{array}$ \\
\hline Armenia & 2000 & 2003 & & & 2003 \\
\hline Azerbaijan & 1999 & & & & \\
\hline Belarus & 1997 & 2003 & 2002 & 2002 & \\
\hline Georgia & 1995 & & 2002 & 2002 & 2000 \\
\hline Kazakhstan & 1999 & & & & \\
\hline Kyrzyzstan & 1999 & 2003 & 2002 & 2002 & 1998 \\
\hline Moldova & 1995 & 1995 & 2002 & 2002 & 2001 \\
\hline Russia & 1995 & 2003 & & & \\
\hline Tajikistan & 2000 & & & & \\
\hline \multicolumn{6}{|l|}{$\begin{array}{l}\text { Turkmeni- } \\
\text { stan }\end{array}$} \\
\hline Ukraine & 1995 & 2002 & 2002 & 2002 & \\
\hline Uzbekistan & & & & & \\
\hline
\end{tabular}


tion contains a key provision that allows nations to adopt their own limitations and exceptions, subject to certain conditions. Article 9(2) states: "It shall be a matter for legislation in the countries of the Union to permit the reproduction of such works in certain special cases, provided that such reproduction does not conflict with a normal exploitation of the work and does not unreasonably prejudice the legitimate interests of the author." Much has been made of this clause, which has come to be known as the "three-step test" for limiting the exclusive rights of authors or copyright holders, in view of the fact that it embodies three concepts. Table 1 provides a list of members of CIS nations in international copyright conventions, treaties, and agreements.

The Agreement on Trade-Related Aspects of Intellectual Property Rights (TRIPS Agreement), the multilateral trade agreement concluded in 1994 and binding for members of the World Trade Organization, is a major international instrument governing copyright internationally. It incorporates the Berne Convention by reference and includes a provision similar to Article 9(2) of Berne. Article 13 of the TRIPS Agreement states: “Members shall confine limitations or exceptions to exclusive rights to certain special cases which do not conflict with a normal exploitation of the work and do not unreasonably prejudice the legitimate interests of the right holder." The 1996 WIPO Copyright Treaty, which expanded on aspects on Berne not sufficiently addressed in the 1971 Paris Act to adapt copyright to the digital age, includes a similar provision in Article 10, as does the 1996 WIPO Performances and Phonograms Treaty, which protects the rights of performers, phonogram producers, and radio, television, broadcasting, and cable organizations under the sphere of neighboring rights in the digital environment, in Article 16. The language in all of these instruments thus gives nations the right to adopt limitations or exceptions to rights as long as the exceptions satisfy the three-part requirement. The Rome Convention, governing neighboring rights, is discussed later in this article. It contains four exceptions for neighboring rights and also allows member nations to adopt the same kinds of limitations with respect to neighboring rights that Berne provides for literary and artistic works.

\section{Categorization of Copyright Limitations and Exceptions}

What kinds of copyright limitations and exceptions have been adopted by nations in their domestic legislation? One of the difficulties in discussing copyright limitations and exceptions is that they have been categorized in a number of different ways by the world's leading copyright specialists. The WIPO Glossary of Terms of the Law of Copyright and Neighboring Rights treats limitations of copyright as synonymous with exceptions and categorizes the main forms of limitations as cases of free use, compulsory licenses, and statutory licenses. ${ }^{14}$

Noted copyright expert Stephen M. Stewart, in his book International Copyright and Neighbouring Rights, outlined three types of exceptions and restrictions on the exclusive rights of the creator of the work that exist in international law: freeuse (fair-use, or fair-dealing) exceptions; nonvoluntary licenses, by which the work may be used without prior consent of the author, subject to certain conditions, such as payment of remuneration to the copyright holder; and exceptions permitted by international conventions for use of the work in developing countries.

He described free-use provisions as being of two kinds - those stipulating free use with respect to a specific purpose for all classes of works and those stipulating 
free use for particular classes of works - and delineated five categories of exceptional free use: exceptions for public speeches, lectures, and speeches in legal proceedings; exceptions established with the aim of freedom of information in press and broadcasting; exceptions for the use of quotations; exceptions for private study and research; and exceptions for reproduction for personal or private use. ${ }^{15}$ In this scheme, the term "free use" is used with respect to all limitations and exceptions except for those governed by nonvoluntary (compulsory) licenses and those pertaining to developing countries.

In discussing exceptions and limitations on exclusive rights, Professor Paul Goldstein, in his book entitled International Copyright, grouped limitations and exceptions into the categories of private uses and public uses. Private uses encompassed scholarship and private study, and research, including reverse engineering. Public uses included parody, press use, instruction, and quotation. He also defined two incidental uses: ephemeral broadcast copies by broadcasting organizations, and computer copies to enable proper utilization. He included the commonly found exhaustion, or first-sale, doctrine, which can work to either allow the owner of a work to transfer ownership without negotiations with the copyright owner or prevent unlawful reproduction of rented phonograms or computer programs. He discussed other exceptions found in national laws, but not explicitly outlined in Berne, including reproduction of published works in Braille, and exceptions to libraries and archives for preservation, for the benefit of users, and for library lending (note that this exemption did not originate in Berne). Forming a separate category were statutory licenses involving equitable remuneration to the author, which he divided into three types: recording of musical works; private copying, such as audio- and videotaping and reproduction of printed works; and translation and reproduction of works in developing countries. ${ }^{16}$

Professor J. A. L. Sterling, in his book entitled World Copyright Law, categorized various areas for which national laws frequently contain limitations and exceptions: private use, including performance within the family circle; private use involving private copying levies to provide some compensation to copyright holders under certain conditions; or private use involving time-shifting of television programs. He outlined additional limitations and exceptions to exclusive rights pertaining to criticism or review of works; education; library and archival activities; research, as sometimes distinguished from private use, which might involve pure entertainment; use of computer programs, involving provisions for the making of backup copies and copying for purposes of observation, study, testing, and decompilation, under certain conditions; and the use of databases, involving acts necessary to ensure normal use of the database and its contents.

Professor Sterling described other types of restrictions, some of which have relevance for CIS laws, including use of protected material by a government, use of works by disabled persons, access to material open to public inspection, news reporting of current events, photographing artistic works that are on public display, uses involving public security, use of works for administrative and judicial procedures, and ephemeral recording by broadcasters. ${ }^{17}$ Included in his discussion of limitations and exceptions were compulsory and statutory licenses, whereby the limitation or exception is only permitted upon compliance with certain procedures, such as payment of royalties; and national laws that include provisions stipulating that a specific right 
may be exercised only through a collective administration society. ${ }^{18}$

Still, one wonders why the task of classifying the various types of limitations and exceptions in copyright laws around the world varies so much among leading copyright specialists. This is no doubt at least partly because the Berne Convention along with other relevant international copyright and neighboring rights treaties do not themselves contain all the exceptions that may exist in copyright laws worldwide. But given the possibilities for widely different types of formulations, there is a surprising consistency among the laws of many nations worldwide, and certainly among the CIS nations, in the range of such provisions incorporated into copyright laws.

The recently published WIPO Study on Limitations and Exceptions of Copyright and Related Rights in the Digital Environment, authored by Professor Sam Ricketson (hereafter referred to as the WIPO Study) provides a lengthy and comprehensive analysis of copyright limitations and exceptions as found in the Berne Convention, Rome Convention, TRIPS Agreement, 1996 WIPO Copyright Treaty, and 1996 WIPO Performances and Phonograms Treaty, with some treatment of individual national approaches. In this study, limitations and exceptions to copyright are grouped in three categories: those that exclude protection for particular categories of works or material, defined as limitations; those that allow for immunity for infringement for particular kinds of use, defined as exceptions; and those that allow a particular use subject to payment of remuneration of the copyright owner, defined as compulsory or obligatory licenses. ${ }^{19}$

It is clear that categorization of limitations and exceptions in copyright law may follow different schemes. As for the present study, and without getting too enmeshed in categories, it is important to see how the various limitations and exceptions provided in Berne have been applied in the copyright laws of the CIS nations and to identify additional limitations and exceptions found in these laws as common practice. The present study refers primarily to the categories as presented in the WIPO Study prepared by Professor Ricketson and discusses "free-use" exceptions, which have the most relevance for libraries and archives. Nonvoluntary licenses (compulsory licenses and statutory licenses) are not within the scope of this article. This comparative analysis will show the purpose of the provision, its implementation in CIS national legislation, and variants in the provisions across the CIS laws.

The WIPO Study classifies three limitations to copyright in the Berne Convention. They concern official texts of a legislative, administrative, and legal nature; news of the day and miscellaneous facts; and political speeches and speeches delivered in the course of legal proceedings. It also identifies numerous exceptions, six of which are discussed here because they are relevant for free use of copyrighted materials in the CIS nations.

\section{CIS Limitations and Exceptions to Copyright Originating in the Berne Convention}

Official Texts of a Legislative, Administrative, and Legal Nature

Article 2(4) of the Berne Convention states:

It shall be a matter for legislation in the countries of the Union to determine the protection to be granted to official texts of a legislative, administrative and legal nature, and to official translations of such texts.

This is an optional limitation. All of the CIS nations contain a provision address- 
ing the protection of official documents, included in an article covering works not protected by copyright. There are two aspects to this provision: the scope of the term "official texts," and whether their official translations are also protected. It is generally accepted that types of official texts other than legislative, administrative, and legal do not come within the scope of this provision.

Strictly speaking, this limitation has been incorporated in domestic CIS laws as a provision indicating the nonprotected nature of official texts, rather than as a provision allowing for free use of official texts that are otherwise protected. This distinction is important to recognize. As for translations of official documents, the WIPO Guide to the Berne Convention for Literary and Artistic Works (hereafter referred to as the WIPO Guide to the Berne Convention) clarifies that at the Stockholm Revision of 1967, official translations were considered to fall under this limitation. ${ }^{20}$ All of the CIS laws exclude protection for official translations.

The wording of this provision differs somewhat in the various laws. The laws of Azerbaijan (Article 7), Belarus (Article 8), Russia (Article 8), and Tajikistan (Article 7) stipulate that works not protected by copyright include "official documents (laws, court decisions, and other texts of a legal, administrative, or judicial nature) and their official translations." Kazakhstan (Article 8) adds to this listing works of a diplomatic nature. Georgia (Article 8 ) uses the word "normative" rather than "legal" or "judicial." Armenia (Article 6), Uzbekistan (Article 8) and Kyrgyzstan (Article 8) use the phrase "official documents (laws, resolutions, decisions, etc.) and their official translations." The Moldovan law (Article 7) is more open-ended, using the phrase "official documents (laws, court decisions, and other documents), and their official translations."
The law of Turkmenistan (Article 1061) excludes from protection "official documents (laws, court decisions, and other texts of an administrative and normative character), and also official translations thereof." The Ukrainian law (Article 10) contains a unique formulation: "official documents of a political, legal, and administrative nature (laws, decrees, resolutions, court decisions, state standards, etc.) and their official translations."

\section{News of the Day and Miscellaneous Facts}

Article 2(8) of the Berne Convention states:

The protection of this Convention shall not apply to news of the day or to miscellaneous facts having the character of mere items of press information.

This is a mandatory limitation. It is interesting that all the CIS nations contain a provision to this effect, whether or not they are currently parties to the Berne Convention. The WIPO Guide to the Berne Convention clarifies that "[T]he news and the facts themselves are not protected nor the simple telling of them, since matters of this kind lack the necessary conditions to be considered as falling into the category of literary and artistic works. This exception merely confirms the general principle that, for a work to be protected, it must contain a sufficient element of intellectual creation." ${ }^{21}$ It therefore can be interpreted against the expressed view that journalistic articles are protected insofar as they are literary or artistic works, as found in the Report of the Main Committee I at the 1967 Stockholm Conference. ${ }^{22}$

The wording in the various CIS laws differs somewhat, but the meanings are consistent, conveying the idea that news of the day and factual information in the press are not protected by copyright. The 
laws of Azerbaijan (Article 7), Kazakhstan (Article 8), Russia (Article 8), Tajikistan (Article 7), and Turkmenistan (Article 1061) contain language that translates as "communications on events and facts of an informational nature." Kyrgyzstan (Article 8) excludes "communications of news or communications concerning events of an everyday informational journalistic nature." Georgia (Article 8) excludes "information on facts and events." Armenia (Article 6), Uzbekistan (Article 8), and Ukraine (Article 10) exclude "communications on news of the day or on current events having the character of ordinary press information." The Moldovan law (Article 7) refers to "news of the day and facts of a simple informational nature." Belarus (Article 8[2]) has the broadest and most concise formulation, excluding "information as such."

\section{Political Speeches and Speeches Delivered in the Course of Legal Proceedings}

Article 2bis(1) of the Berne Convention states:

It shall be a matter for legislation in the countries of the Union to exclude, wholly or in part, from the protection provided by the preceding Article political speeches and speeches delivered in the course of legal proceedings.

This limitation is optional. This provision was introduced at the Rome Revision (1928) and has remained unchanged, and its justification is freedom of information. ${ }^{23}$ It is qualified by Article 2bis(3), which states: "Nevertheless, the author shall enjoy the exclusive right of making a collection of his works mentioned in the preceding paragraphs." It is also closely related to Article 2bis(2), which deals with publicly delivered lectures and addresses reproduced by the press, and is discussed below.
In most of the CIS laws, this provision is included in a general provision on "use of a work without consent of the author and without payment of royalties" or "free use of a work with indication of the author's name." Several ideas are implicit in this provision, as qualified by Article 2bis(3), some or all of which are incorporated into the various domestic laws because this provision is optional: the extent of the exclusion; reproduction of publicly delivered political speeches; reproduction of legal speeches; and retention by the author of the right to include such a work in a compilation. The CIS provisions also contain a further qualification concerning the nature of the reproduction: they all indicate that this provision applies to reproduction for the press and broadcasting media.

The laws of Armenia (Article 13) and Uzbekistan (Article 28) contain the most generic formulations, allowing reproduction in the press and the broadcast of publicly delivered political speeches, lectures, addresses, and other similar works, to the extent justified by the intended purpose of the information, without consent of the author or other copyright holder and without payment of remuneration, but with an indication of the author's name and of the source of the borrowing. The Uzbek law adds the condition that the reproduction must not conflict with a normal exploitation of the work and must not compromise the lawful interests of the author.

All of the CIS laws specify that the works excluded from protection must be publicly delivered, but Belarus (Article 19), Moldova (Article 22[1][b]), Tajikistan (Article 20[4]), and Ukraine (Article 21[9]) do not include any political qualification; Moldova specifies that the works must be on current topics. Only three, Azerbaijan (Article 19[5]), Georgia (Article 23[e]), and Turkmenistan (Article 1087[e]), include 
wording for the category of speeches delivered in the course of legal proceedings. All except Azerbaijan and Moldova restrict the amount of the work that can be reproduced to "the extent justified by the informational (or intended) purpose"; Moldova specifies that they be excerpts. Azerbaijan, Georgia, Kazakhstan (Article 19[4]), Kyrgyzstan (Article 19[4]), Russia (Article 19[4]), Tajikistan, and Turkmenistan contain the reservation that the author reserves the exclusive right to publication of such works in a separate collection or book. Turkmenistan adds the word "prophecies" to the list of types of works that may be reproduced.

Thus, there is quite a bit of variation in this provision across the laws. Part of this might be attributed to an attempt on the part of these nations to combine the concepts of Berne Articles 2bis(1) and $2 b i s(2)$. This is discussed below.

\section{Quotations}

Article 10(1) of the Berne Convention states:

It shall be permissible to make quotations from a work which has already been lawfully made available to the public, provided that their making is compatible with fair practice, and their extent does not exceed that justified by the purpose, including quotations from newspaper articles and periodicals in the form of press summaries.

This is a mandatory exception for Berne member states. It is subject to the terms of Article 10(3), which requires that mention be made of the source and of the name of the author if it appears on the work. All of the CIS nations contain a provision to this effect. There are four main elements to this provision, as it is qualified by Article 10(3): that the work from which quotation is made has been lawfully made available to the public; that the use is compatible with fair practice; that the extent of the use is justified by the purpose of the quotation; and that the source and name of the author is identified.

In all cases except Ukraine (Article 21[1]) and Uzbekistan (Article 28), the requirement for the work to have been lawfully made available to the public is satisfied by the phrasing "lawfully published" or "lawfully promulgated." In those two cases the phrasing is simply "published." The "fair-practice" requirement is not stated explicitly in the CIS laws, but each law specifies purposes for quotations that serve to indicate what is considered "fair."

Quotation for scientific, critical, informatory, or educational purposes was discussed in preparatory work for the Stockholm Conference as being within the scope of Article 10(1), hence that is where the list originates, but a list of purposes was not included in the final revision. ${ }^{24}$ In the laws of Armenia (Article 13), Azerbaijan (Article 19[1]), Georgia (Article 23[a]), Kazakhstan (Article 19[1]), Kyrgyzstan (Article 19[1]), Russia (Article 19[1]), Tajikistan (Article 20[1]), and Turkmenistan (Article 1087[a]), five valid purposes are included: scientific, research, polemical, critical, and informational. Belarus (Article 19) adds educational use to the listing, Moldova (Article 22[a]) and Ukraine do not specify research as a justifiable purpose, and Uzbekistan does not specify polemical use as a justifiable purpose. All of the laws specify that quotation is allowed only to the extent justified by the intended purpose of the quotation. All of the laws except Ukraine's specify that quotation may be made from the original work as well as from a translation.

All of the CIS provisions require the indication of the author and the source. The Ukrainian provision adds permis- 
sion to "freely use quotations in the form of brief excerpts from performances and works incorporated in a phonogram (videogram) or a broadcasting program," evidently reinforcing its obligations under the WIPO Performances and Phonograms Treaty. The Moldovan provision (Article 22) offers very specific guidelines for free use of works. The quotation of an isolated extract in prose must not exceed four hundred words. In quoting from several excerpts from one work, the amount of prose may not exceed three hundred words from each extract (but not constituting more than one author's page ${ }^{25}$ ) and the amount of poetry may not exceed forty lines (but not constituting more than one-fourth of the work of poetry).

The inclusion of the words "in the form of press summaries" in the Berne Convention has been acknowledged as confusing. ${ }^{26}$ It is generally understood as a relic of the past when quotations and press reviews were linked, and the distinction appears to be largely irrelevant today. ${ }^{27}$ The latest revision of Berne does not include the adjective "short" to qualify the word "quotations," which was included in the Brussels Revision of 1948 but later removed..$^{28}$ The laws of Armenia and Belarus restrict quotation to "excerpts," conveying the idea that only smaller portions may be used for quotation. Ukraine further qualifies the portion of the work that may be used in quotation to "brief excerpts."

\section{Use of Works for Teaching}

Article 10(2) of the Berne Convention states:

It shall be a matter for legislation in the countries of the Union, and for special agreements existing or to be concluded between them, to permit the utilization, to the extent justified by the purpose, of literary or artistic works by way of illustration in publications, broadcasts or sound or visual recordings for teaching, provided such utilization is compatible with fair practice.

This exception is optional. Five ideas are present here: that the use is from literary and artistic works; that the use is for illustration in teaching; that it is in the form of publication, broadcast, or sound or visual recording; that the extent of the use is justified by the purpose; and that the use is consistent with fair practice. This provision is subject to the terms of Article 10(3), which requires that mention be made of the source and of the name of the author if it appears on the work. By way of comparison, this provision is implemented in U.S. law in Section 110 of the 1976 Copyright Act, which was recently revised by the TEACH Act.

The purpose of Article 10(2) is "to meet teaching needs." At the Stockholm Revision of 1967, there was agreement that this provision encompassed teaching at all levels, "in educational institutes, municipal and state schools, and private schools," but that it did not include within its scope the concept of scientific research. ${ }^{29}$ Professor Ricketson has clarified that the intention of the delegates at the Stockholm Conference was to exclude teaching outside those types of institutions, therefore teaching for the general public would not be included under this provision. ${ }^{30}$

All of the CIS nations except Moldova have incorporated this provision into their laws. All indicate that the use is for illustration in teaching and that it is in the form of publication, broadcast, or sound or visual recording. All require the indication of the source and the name of the author, and require that the extent of the use be justified by the purpose, but none explicitly includes the phrase concerning compatibility with fair practice. In ad- 
dition, all include the qualification that works be lawfully published or disclosed, indicating that unpublished works may not be used in this manner. Armenia (Article 13) and Ukraine (Article 21[2]) specify that the provision applies to "literary and artistic works." The other laws indicate simply "works." Uzbekistan (Article 28) uses the qualification "disclosed."

The word "extracts" was removed from the text of the Berne Convention with the Stockholm Revision of 1967. ${ }^{31}$ It is interesting that two nations, Azerbaijan (Article 19[2]) and Belarus (Article 19), restrict the use to "excerpts" (synonymous with extracts) of works; and Georgia (Article 23[b]) and Turkmenistan (Article 1087[b]) restrict use to "short excerpts." Some of the laws include language encompassing use of both works and excerpts of works: Armenia, Kazakhstan (Article 19[2]), Kyrgyzstan (Article 19[2]), Russia (Article 19[2]), Tajikistan (Article 20[2]).

Moldova does not include a provision of this type but does allow reproduction of a work without gainful intent in isolated situations and to the extent justified by the purpose by educational institutions of lawfully published separate articles and other small works or short excerpts from written works (with the exception of computer programs) for classroom use. That provision more closely resembles another on reproduction for libraries, archives, and educational institutions, which is also common to CIS laws, though not originating in Berne, and which is discussed below.

\section{Reproduction by the Press, Broadcast- ing, or Public Communication by Wire of Articles in Newspapers and Periodicals} Article 10bis(1) of the Berne Convention states:

It shall be a matter for legislation in the countries of the Union to permit the reproduction by the press, the broadcasting or the communication to the public by wire of articles published in newspapers or periodicals on current economic, political, or religious topics, and of broadcast works of the same character, in cases in which the reproduction, broadcasting or such communication thereof is not expressly reserved. Nevertheless, the source must always be clearly indicated; the legal consequences of a breach of this obligation shall be determined by the legislation of the country where protection is claimed.

This is an optional exception, originating in Berne for the benefit of the press. The CIS nations all have a provision to this effect in their copyright laws. Five ideas are embodied in this provision: that the subject of the provision is published items in newspapers and periodicals and broadcast works; that the works in question are on current economic, political, or religious topics; that the use involves reproduction in the press or public communication; that the use is made only if not expressly reserved; and that the source is indicated. All of the laws include similarly worded provisions expressing all of these concepts. All the laws except that of Tajikistan (Article 20[3]) include the additional adjective "social" to qualify the range of topics. Belarus (Article 19) contains the language "economic, political, social, and other." The Moldovan law Article 22(1)(b) specifies that the use may be from an original or a translation but does not include a restriction to cases in which the use is not expressly reserved. The Georgian law (Article 23[c]) adds that the author retains the right to publication of such works in collections.

The laws of Armenia (Article 13), Azerbaijan (Article 19[3]), Belarus, Geor- 
gia, Russia (Article 19[3]), Tajikistan, and Turkmenistan (Article 1087[c]) specify that the work reproduced must be lawfully published. The provision is also found in the laws of Kazakhstan (Article 19[3]), Kyrgyzstan (Article 19[3]), Ukraine (Article 21[3]), and Uzbekistan (Article 28).

\section{Reproduction by the Press, Broadcasting,} or Public Communication by Wire of Lectures, Addresses, and Other Similar Works Article 2bis(2) of the Berne Convention states:

It shall also be a matter for legislation in the countries of the Union to determine the conditions under which lectures, addresses and other works of the same nature which are delivered in public may be reproduced by the press, broadcast, communicated to the public by wire and made the subject of public communication as envisaged in Article $11 b i s(1)$ of this Convention, when such use is justified by the informatory purpose.

This is an optional exception originating in Berne, also for the benefit of the press. Only some of the CIS nations contain a provision to this effect. This is not to be confused with provision $2 b i s(1)$ concerning political speeches and legal speeches made in the courtroom. It is qualified by Article 2bis(3), which states: "Nevertheless, the author shall enjoy the exclusive right of making a collection of his works mentioned in the preceding paragraphs."

There are several aspects to this provision: it applies to publicly delivered oral works; the use involves reproduction in the press or public communication; the use must be justified by the informatory purpose; and the author retains the right to publication of the work in collections.
There are no restrictions on subject matter. The CIS laws treat this provision in various ways because it would appear that most have attempted to combine the requirements of Berne articles 2bis(1) and 2 bis(2). In most of the laws, there is an overlapping of concepts in one provision.

Strictly speaking, only Tajikistan (Article 20[4]) has a provision containing all of the elements stipulated in this Berne article. The laws of Belarus (Article 19) and Ukraine (Article 21[9]) include a provision concerning publicly delivered speeches, permitting reproduction to an extent justified by the purpose, but they do not contain a reservation to the effect that the author reserves the exclusive right to publication of such works in a separate collection or book. The Moldovan law (Article 22[1][b]) refers to publicly delivered speeches and addresses on current topics but does not include wording about justified use or retention of the author's exclusive right to publication.

The other CIS laws contain provisions more closely resembling Berne Article $2 b i s(1)$, as the list of oral works is qualified with the adjective "political." Such provisions are found in the laws of Armenia (Article 13), Azerbaijan (Article 19[5]), Georgia (Article 23[e]), Kazakhstan (Article 19[4]), Kyrgyzstan (Article 19[4]), Russia (Article 19[4]), Turkmenistan (Article 1087[e]), and Uzbekistan (Article 28).

\section{Incidental Reproduction of Works in the Course of Reporting Current Events}

Article 10bis(2) of the Berne Convention states:

It shall also be a matter for legislation in the countries of the Union to determine the conditions under which, for the purpose of reporting current events by means of photography, cinematography, broadcast- 
ing or communication to the public by wire, literary or artistic works seen or heard in the course of the event may, to the extent justified by the informatory purpose, be reproduced and made available to the public.

This is an optional exception, and like the previous two exceptions, it originated for the benefit of the press. Several ideas are present here: that the purpose of the reproduction and making available to the public is the reporting of current events; that the reproduction is made only by means of photography, cinematography, or public broadcast or communication; that the subject is literary and artistic works seen or heard incidentally in the reporting of current events; and that the extent of the reproduction and making publicly available is justified by the informatory purpose. All of the CIS laws except those of Moldova contain a provision including all the elements found in Berne article 10bis(2). They are found in the laws of Armenia (Article 13), Azerbaijan (Article 19[4]), Belarus (Article 19), Georgia (Article 23[d]), Kazakhstan (Article 19[5]), Kyrgyzstan (Article 19[5]), Russia (Article 19[5]), Tajikistan (Article 20[5]), Turkmenistan (Article 1087[d]), Ukraine (Article 21[4]), and Uzbekistan (Article 28). Azerbaijan, Kazakhstan, Kyrgyzstan, Russia, Tajikistan, and Turkmenistan add that he author retains the right to publication of such works in collections.

\section{Ephemeral Recordings by Broadcast Organizations}

Article 11bis(3) of the Berne Convention states:

In the absence of any contrary stipulation, permission granted in accordance with paragraph (1) of this Article shall not imply permission to record, by means of instruments recording sounds or images, the work broadcast. It shall, however, be a matter for legislation in the countries of the Union to determine the regulations for ephemeral recordings made by a broadcasting organization by means of its own facilities and used for its own broadcasts. The preservation of these recordings in official archives may, on the ground of their exceptional documentary character, be authorized by such legislation.

Article 11bis(3) modifies 11bis(1) (the exclusive right of authors to works to permit their broadcast or communication to the public) by permitting member states to introduce regulations on the production and short-term preservation of recordings of broadcast works by broadcasting organizations. It makes a distinction between the broadcasting of a work, governed by that exclusive right, and the recording of the broadcast work. Several elements are in this exception: the recording must be made by a broadcasting organization by means of its own facilities and used for its own broadcasts; national law may allow that if the recording is of an exceptional documentary character, it may be retained in official archives without consent of the author; and national law defines the meaning of "ephemeral."

All of the CIS nations except Ukraine contain provisions to this effect. They are found in the laws of Armenia (Article 17), Azerbaijan (Article 23), Belarus (Article 37), Georgia (Article 27),

Kazakhstan (Article 25), Kyrgyzstan (Article 24), Moldova (Article 32), Russia (Article 24), Tajikistan (Article 21[4]), Turkmenistan (Article 1091), and Uzbekistan (Article 33). As this provision appears in CIS laws, the use may be made without the consent of the author or other 
copyright holder and without payment of additional remuneration. All of the laws except Moldova's permit the preservation of these recordings in official archives without the author's consent if they are of an exceptional documentary character. Armenia makes a distinction between sound recording and video recording and allows them both.

The Berne Convention leaves the interpretation of "ephemeral" to national legislation, and it has been interpreted in a number of different ways. The CIS nations with this provision all interpret "ephemeral" as a period of six months from the making of the recording, unless a longer period has been agreed upon with the author of the recorded work. The WIPO Guide indicates that preservation in official archives usually means that one copy may be retained for historical purposes. $^{32}$ Table 2 further explains the free-use copyright limitations and exceptions among the CIS nations.

\section{Article 9(2) of the Berne Convention}

Article 9(2) of the Berne Convention states:

It shall be a matter for legislation in the countries of the Union to permit the reproduction of such works in certain special cases, provided that such reproduction does not conflict with a normal exploitation of the work and does not unreasonably prejudice the legitimate interests of the author.

This provision, commonly referred to today as the three-step test, is the basis for many types of exceptions involving reproduction for personal or private use, and research, science, teaching, and classroom use, that are found in national legislation but are not explicitly outlined in Berne. The underlying rationale for such provisions is that the use should not cause loss of profit to the author or other copyright holder, but any provision created under the terms of this article also extends to the moral rights of the author. This article opens up possibilities for nations to restrict the exclusive right of reproduction and at the same time limits conditions under which provisions to this effect may be introduced to certain special cases that do not conflict with the normal exploitation of the work and do not unreasonably prejudice the legitimate interests of the author. The following are exceptions to the exclusive rights of authors and other copyright holders that do not originate in the Berne Convention but are present in copyright laws of the CIS nations and are considered justified by Berne Article 9(2).

\section{Other CIS Copyright Limitations and Exceptions \\ Personal Use}

The "fair-use" doctrine in the United States and the "personal- or private-use" exceptions in other nations are considered to be justified by Berne Article 9(2). Personal- or private-use exceptions are common in national copyright laws worldwide. $^{33}$

All of the CIS nations include a provision for personal use as is a limitation to the right of reproduction (solely the right of reproduction). In all of the CIS laws, it allows for reproduction without consent of author or payment of royalties of a lawfully disclosed work exclusively for personal use or for the personal use of the members of a family. Several concepts are involved in this provision:

- reproduction, without consent of author or other copyright holder, and without payment of remuneration (see exception for phonograms and audiovisual works below), of a lawfully promulgated work exclusively for personal use or for 
Fair Use and Beyond 485

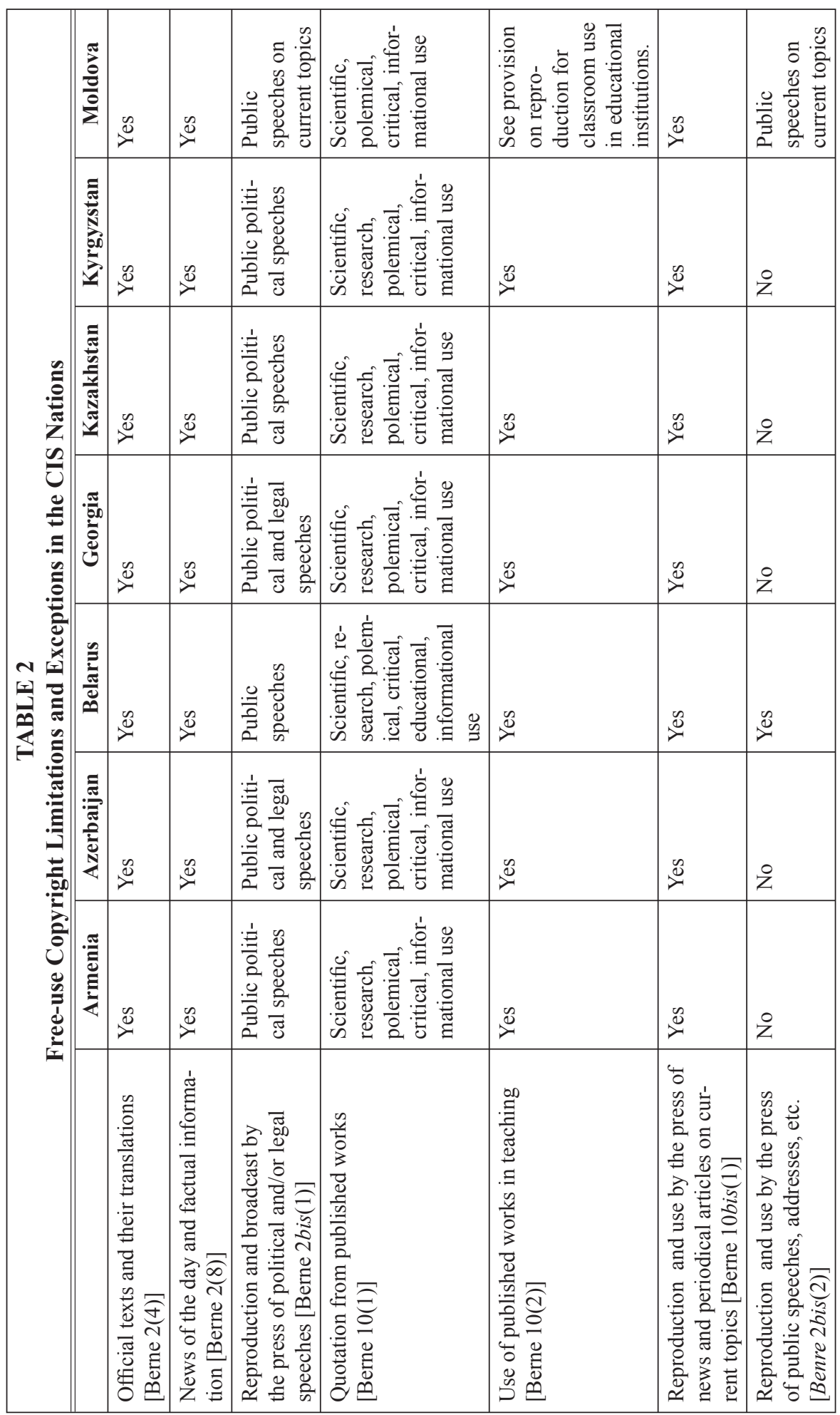




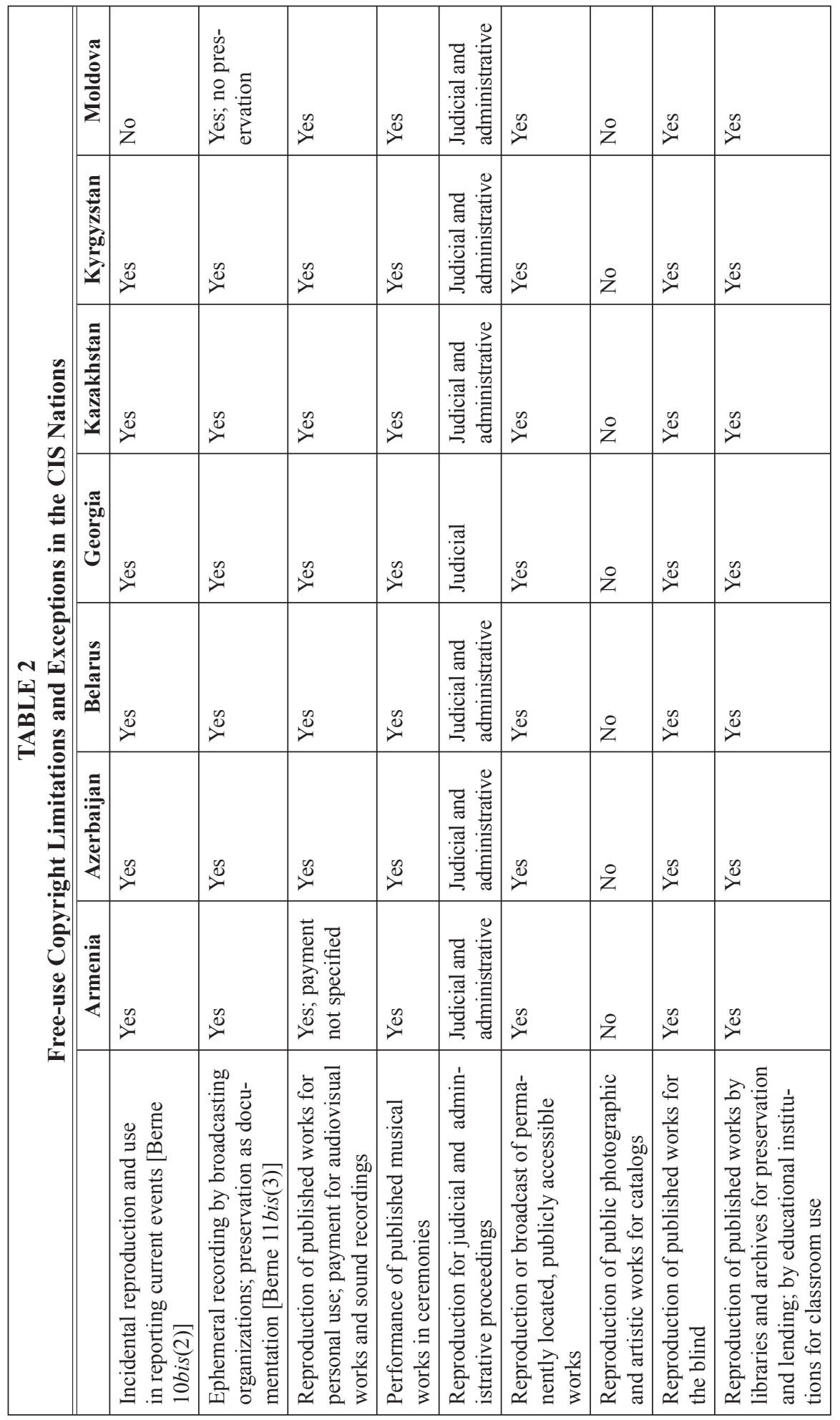


Fair Use and Beyond 487

\begin{tabular}{|c|c|c|c|c|c|c|c|c|c|}
\hline & $\frac{\pi}{\tilde{z}}$ & $\stackrel{\infty}{\infty}$ & 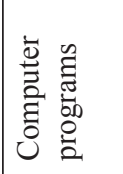 & $\triangleq$ & $\stackrel{0}{2}$ & $\stackrel{\circlearrowright}{2}$ & 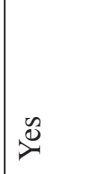 & $\stackrel{0}{2}$ & $\stackrel{0}{2}$ \\
\hline & 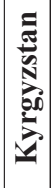 & $\ddot{z}$ & 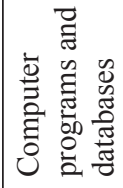 & $\stackrel{\infty}{2}$ & $\stackrel{\infty}{\infty}$ & $\stackrel{\infty}{\infty}$ & $\stackrel{\infty}{\infty}$ & $\sum^{\infty}$ & $\stackrel{\infty}{\infty}$ \\
\hline 兽 & 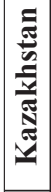 & $\stackrel{\infty}{\infty}$ & 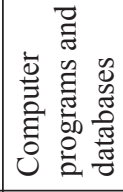 & $\triangleq$ & $\stackrel{\infty}{\infty}$ & $\stackrel{\infty}{\infty}$ & $\stackrel{\infty}{\infty}$ & $\underbrace{\infty}$ & $\stackrel{\infty}{\infty}$ \\
\hline 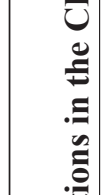 & U⿺辶. & $\stackrel{0}{z}$ & 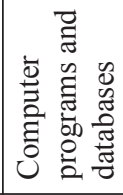 & 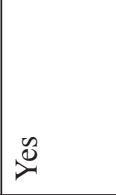 & $\stackrel{\infty}{\infty}$ & $\stackrel{\infty}{0}$ & $\stackrel{\infty}{\infty}$ & $\sum^{\infty}$ & $\dot{z}$ \\
\hline 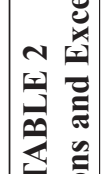 & صُ & $\ddot{z}$ & 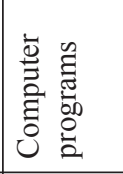 & 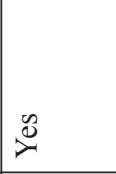 & $\stackrel{\infty}{\infty}$ & $\stackrel{\infty}{0}$ & $\stackrel{\infty}{\infty}$ & $\stackrel{0}{\infty}$ & 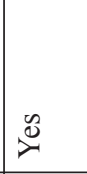 \\
\hline | & 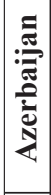 & $\stackrel{z}{z}$ & 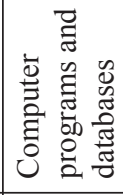 & $\triangleq$ & $\stackrel{\infty}{\infty}$ & $\stackrel{\infty}{\infty}$ & $\stackrel{\infty}{\infty}$ & 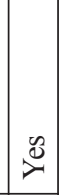 & $\stackrel{0}{2}$ \\
\hline 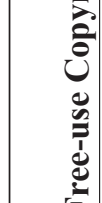 & 营 & z & 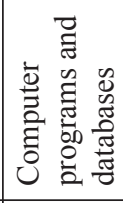 & 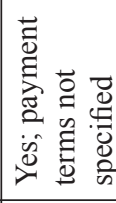 & 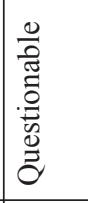 & 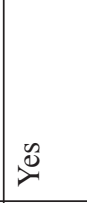 & 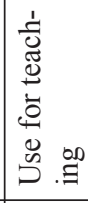 & $\stackrel{0}{\infty}$ & $\stackrel{0}{\infty}$ \\
\hline & & 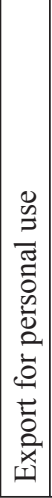 & 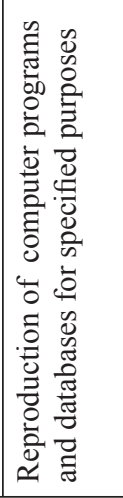 & 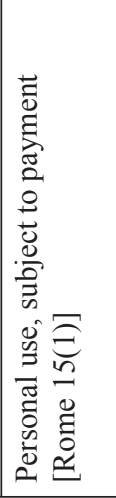 & 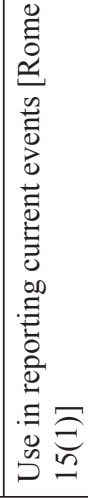 & 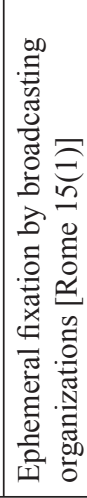 & 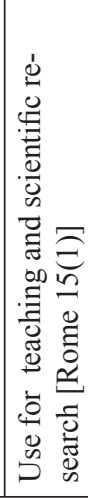 & 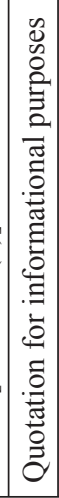 & 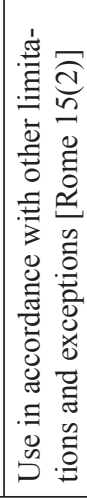 \\
\hline
\end{tabular}




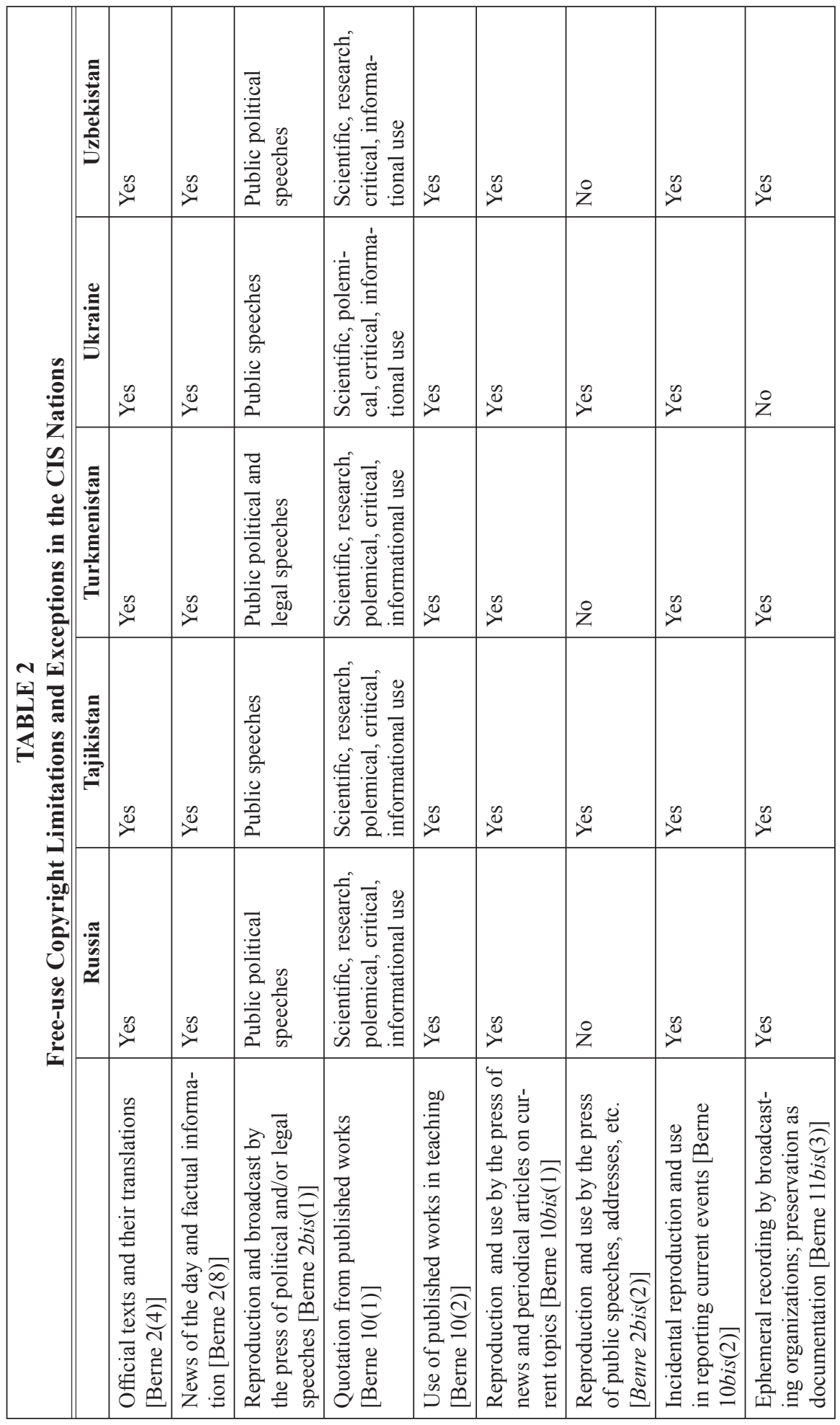




\begin{tabular}{|c|c|c|c|c|c|c|c|c|c|c|c|}
\hline \multirow{6}{*}{$\frac{1}{2}$} & 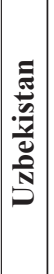 & $\stackrel{\infty}{\infty}$ & $\overbrace{\nu}^{\infty}$ & 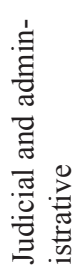 & $\stackrel{0}{\infty}$ & z & $\stackrel{\infty}{\infty}$ & $\stackrel{\infty}{\infty}$ & z & 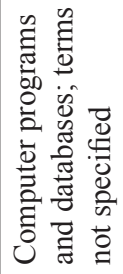 & $\stackrel{\infty}{\infty}$ \\
\hline & 兽 & $\stackrel{\infty}{\infty}$ & $\stackrel{\infty}{\infty}$ & 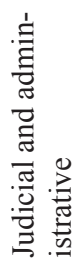 & $\stackrel{0}{z}$ & $\stackrel{\infty}{\infty}$ & $\stackrel{\infty}{\infty}$ & $\stackrel{\infty}{\infty}$ & z & 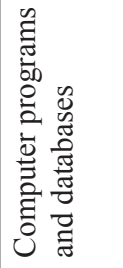 & $\stackrel{\infty}{\infty}$ \\
\hline & 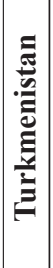 & $\stackrel{\infty}{\infty}$ & $\stackrel{\theta}{\nu}$ & 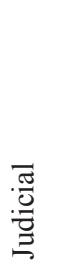 & $\stackrel{\infty}{\infty}$ & z & $\stackrel{0}{\infty}$ & $\stackrel{0}{\infty}$ & ż & 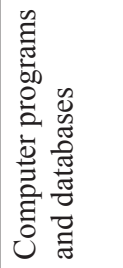 & $\stackrel{0}{\infty}$ \\
\hline & 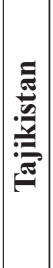 & $\stackrel{0}{\infty}$ & $\stackrel{\infty}{\infty}$ & 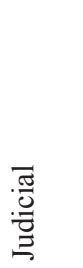 & $\stackrel{0}{\nu}$ & $\stackrel{0}{z}$ & 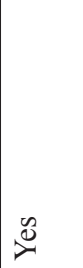 & $\stackrel{0}{\infty}$ & z & 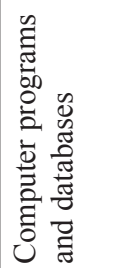 & $\stackrel{\infty}{\infty}$ \\
\hline & 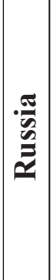 & $\stackrel{\infty}{\nu}$ & $\stackrel{e}{e}$ & 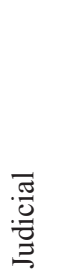 & $\stackrel{0}{\infty}$ & $\stackrel{\circ}{z}$ & $\triangleq$ & $\stackrel{\infty}{2}$ & z & 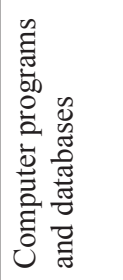 & $\stackrel{e}{e}$ \\
\hline & & 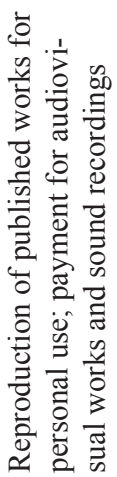 & 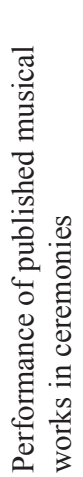 & 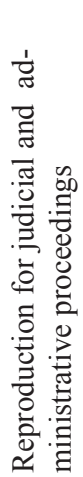 & 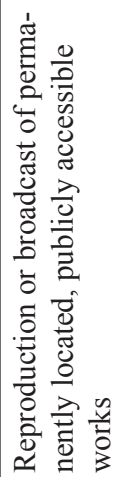 & 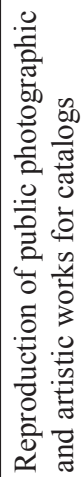 & 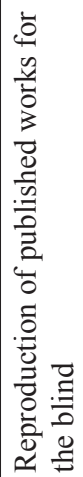 & 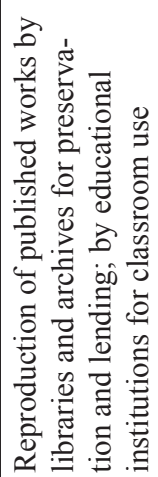 & 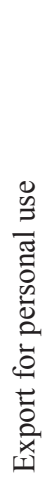 & 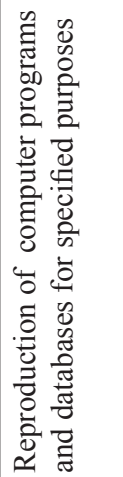 & 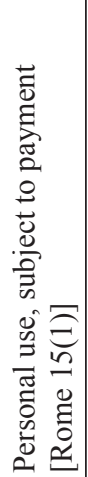 \\
\hline
\end{tabular}




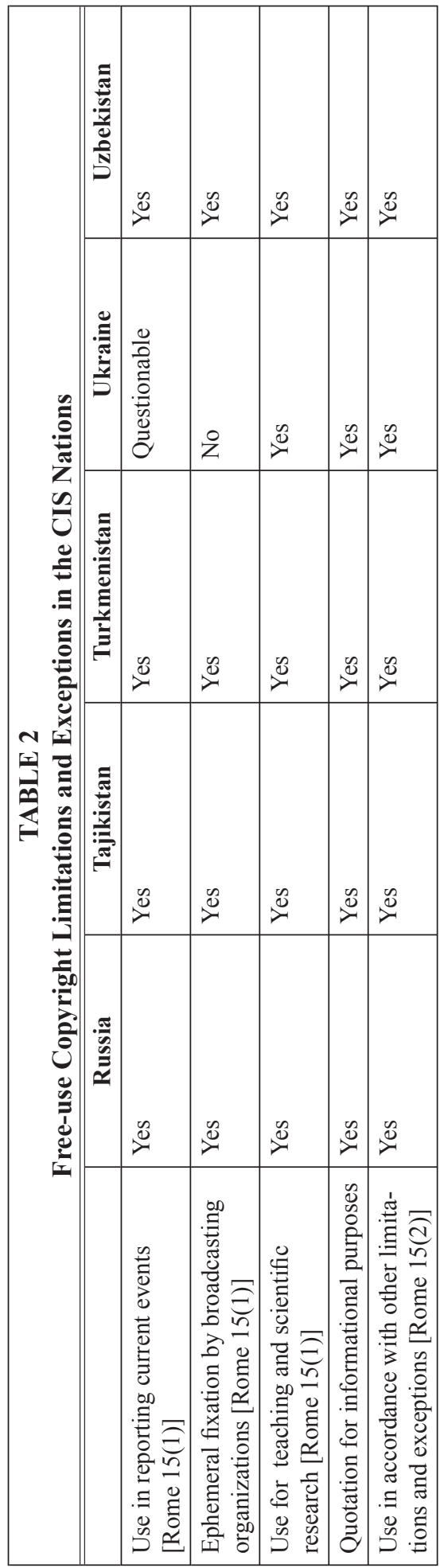

the personal use of the members of the family circle; in most cases, the provision specifies that only one copy may be reproduced;

- stipulation that such reproduction does not apply to architectural works in the form of buildings or other similar works; databases or substantial portions thereof; computer programs, except as allowed in a separate article dealing with reproduction of computer programs; reprographic reproduction of original books in full or of musical notation and, in some of the laws, of works of fine art;

- stipulation, in some laws through a separate article, that for reproduction of an audiovisual work or sound recording, the author or copyright holder is entitled to remuneration;

- stipulation, in some laws through a separate article, that remuneration for reproduction of an audiovisual work or sound recording is to be paid by the manufacturers or importers of the equipment (audio and video recorders and other equipment) and of the recording material (sound and video tapes, cassettes for sound or video recording, optical discs, compact discs, and other media) used for such reproduction; this is known as the private copying levy. ${ }^{34}$

All of the CIS laws contain these elements, with minor variations. The Russian provision (Article 18) is the most typical. Azerbaijan (Article 17), Belarus (Article 18), Kazakhstan (Article 18), Kyrgyzstan (Article 18), and Moldova (Article 20) specify that only one copy may be reproduced. The laws of Azerbaijan, Georgia (Article 21), and Turkmenistan (Article 1082) include works of fine art in the list of exceptions. Tajikistan (Article 19) and Uzbekistan (Article 27) incorporate the Berne language in their provisions, stating that reproduction is allowed without consent of author (or other copyright holder) or remuneration, when there is no conflict 
with the normal exploitation of the work and when the lawful interests of the author are not compromised. Ukraine's provision (Article 25) expands the definition of personal use in the family circle to "exclusively for personal purposes or for a regular family and for close acquaintances of the family." The Armenian (Article 14) provision makes no mention of payment for use of audiovisual works or sound recordings. The Moldovan provision adds that it does not apply to unlawful reproduction of works publicly displayed in the interactive environment. It also permits the temporary reproduction of works to enable the process of electronic transmission or display, subject to the condition that the work is deleted automatically to prevent any other viewing or use for any other purpose.

Some of the laws contain a separate article for personal use involving reproduction of audiovisual works and sound recordings. They are: Kazakhstan (Article 26), Kyrgyzstan (Article 26), Russia (Article 26), Tajikistan (Article 39), Turkmenistan (Article 1083), and Ukraine (Article 42). All the laws except Armenia's include the provision concerning the private copyright levy on audiovisual works and sound recordings: Azerbaijan (Article 17), Belarus (Article 18), Georgia (Article 21), Kazakhstan (Article 26), Kyrgyzstan (Article 26), Moldova (Article 20(3)), Russia (Article 26), Tajikistan (Article 39), Turkmenistan (Article 1084), Ukraine (Article 42), and Uzbekistan (Article 27).

\section{Musical Performances of a Ceremonial Nature}

In 1933, the International Office of the Berne Union recognized as a common provision in many national laws the "unauthorized public performance of works in particular circumstances," such as religious worship, concerts given by military bands, charitable performances, or concerts celebrating public festivals or holidays. This is considered a minor exception, not the subject of specific provisions in the Berne Convention, but referred to in reports of both the Brussels and Stockholm Conferences. ${ }^{35}$

It is significant that all of the CIS laws contain a provision to this effect. Several ideas are embodied in the various versions of this provision across the CIS laws: that the musical work is lawfully disclosed; that the performance is during official, religious, or ritual ceremonies, and in most of the laws, funerals are specified; that the extent is justified by the nature of the ceremony; and that the use can be made without the consent of the author or other copyright holder and/or without remuneration. It is not specified that the performances must be organized by the state. ${ }^{36}$

In many cases, this provision is included in the provision for "free use of works" or "use of a work without the consent of the author and without remuneration," or in a separate article on "free public performance" or "public performance of musical works during ceremonies." The laws of Armenia (Article 13), Moldova (Article 22[d]), and Ukraine (Article 21[8]) require mention of the author's name and source of the work. The laws of Azerbaijan (Article 21), Georgia (Article 25), Kazakhstan (Article 22), Kyrgyzstan (Article 22), Russia (Article 22), Tajikistan (Article 21[2]), Turkmenistan (Article 1089), and Uzbekistan (Article 31) do not specify whether the author and the source should be mentioned. Belarus (Article 19) specifies that indication of author and source are not required. Neither Armenia nor Belarus includes funerals in the list of types of performances, but this is probably not a relevant omission because funerals are generally considered to be ritual ceremonies. 


\section{Use of Material for Court and Administrative Proceedings}

A relatively straightforward exception found in all of the CIS laws, with minor variations, allows for reproduction of a work without the author's or other copyright holder's consent and without payment of remuneration for the purposes of judicial or administrative proceedings, to the extent justified by the purpose of the use. Some laws require indication of name of the author or the source of the borrowing.

In some cases, this constitutes a separate article in the laws; in others, it is a provision in the article dealing with "free use of works" or "use of a work without consent of the author and without payment of remuneration." Such a provision is found in the laws of Armenia (Article 13), Azerbaijan (Article 22), Belarus (Article 19), Georgia (Article 26), Kazakhstan (Article 23), Kyrgyzstan (Article 23), Moldova (Article 22[e]), Russia (Article 23), Tajikistan (Article 21[3]), Turkmenistan (Article 1090), Ukraine (Article 21[7]), and Uzbekistan (Article 32). Belarus, Moldova, and Ukraine require indication of the author's name and the source of the borrowing. Georgia, Russia, Tajikistan, and Turkmenistan apply this provision only to judicial proceedings; their provisions do not include administrative proceedings.

\section{Works in Public Places}

Another limitation common to all of the CIS laws is one that allows for reproduction, broadcasting, or public cable transmission, without the consent of the author or payment of remuneration, of architectural works, photographic works, or works of fine art permanently located in a publicly accessible location, except where the image of the work is the main object of the reproduction, broadcast, or transmission or when the image is being used for commercial purposes.
The provisions are formulated uniformly across the laws, with the exception of Ukraine's. In some laws, they constitute a separate article; in others, they appear within a larger provision. They are found in the laws of Armenia (Article 16), Azerbaijan (Article 20), Belarus (Article 19), Georgia (Article 24), Kazakhstan (Article 21), Kyrgyzstan (Article 21), Moldova (Article 22[f]), Russia (Article 21), Tajikistan (Article 21[1], Turkmenistan (Article 1088), and Uzbekistan (Article 30). Ukraine does not have a provision of this type.

\section{Reproduction of Works for Illustrated Catalogs}

A lesser-known provision that appears only in the law of Ukraine allows reproduction in exhibition or sales catalogs of photographs of artistic works exhibited to the public. ${ }^{37}$ This provision is distinct from the limitation involving reproduction of works of art in public places. Article 21(5) of the Ukrainian law permits the reproduction in catalogs of the works displayed at exhibitions, auctions, fairs, and collections that are open for public access.

\section{Reproduction of Works in Braille}

All of the CIS laws contain a provision that allows for the reproduction in Braille or by other special means appropriate for the blind, without gainful intent, of a lawfully disclosed work, with the exception of works created specifically for such means of reproduction. The reproduction is authorized without consent of the author and without payment of remuneration but requires indication of the name of the author and the source of the borrowing. In most cases, the provision forms part of a larger article on "free use of works" or "use of a work without consent of the author and without payment of remuneration." 
Such provisions are found in the laws of Armenia (Article 13), Azerbaijan (Article 19[6]), Belarus (Article 19), Georgia (Article 23[f]), Kazakhstan (Article 19[6]), Kyrgyzstan (Article 19[6]), Moldova (Article 22[c]), Russia (Article 19[6]), Tajikistan (Article 20[6]), Turkmenistan (Article 1087[f]), Ukraine (Article 21[6]), and Uzbekistan (Article 28). The Ukrainian law contains a brief formulation for "issuance of works for the blind, published in Braille characters."

\section{Reproduction by Libraries, Archives, and Educational Institutions}

This is the key provision underlying library and archival reproduction of material for users, for internal preservation and replacement purposes, and for reproduction for library lending. It also is the provision behind educational copying for classroom use. In this respect, there might appear to be an overlap with provisions modeled on Berne Article 10(2) involving reproduction for purposes of illustration in teaching. The difference is that this provision allows for reproduction of copies for students, whereas Berne Article 10(2) governs use of a work as a classroom illustration only.

As it concerns educational institutions, the provision governs reproduction of works for the classroom, but not including use in broadcasts or sound and visual recordings for illustrative use as allowed by Berne Article 10(2). Because it concerns reproduction by libraries and archives of material for users, it includes within its scope scientific research (not merely education/teaching) and even personal use in some laws. All of the CIS laws contain this provision, and in all of the laws except those of Tajikistan and Ukraine, it constitutes a separate article; the Tajik law includes it in the article on "use of a work without consent of the author and without payment of remuneration but with indication of author and source." The Ukrainian law divides the content of this provision into two articles, one on libraries and archives and the other on educational institutions.

Several elements in this provision are common to all the laws, with some variation:

- The reproduction is permitted without consent of author (or other copyright holder) and without payment of remuneration, but with mandatory indication of the name of the author (or other copyright holder), the work in some cases, and the source of the borrowing.

- The reproduction must be without commercial motive (gainful intent).

- The reproduction is limited to one copy.

- The reproduction is from lawfully published or disclosed works.

- Libraries and archives may reproduce works for the purpose of preservation or replacement of lost, damaged, or destroyed copies, or copies that have become unusable.

- Libraries and archives may reproduce works to provide copies to other libraries that have for any reason lost the work from their collections.

- Libraries and archives may reproduce works to provide copies upon request to individuals for study, educational, or research purposes (in some laws also for personal use); individual articles and short works lawfully published in collections, newspapers, and other periodical publications; or brief extracts from lawfully published written works (some laws explicitly exclude computer programs).

- Educational institutions may reproduce, for classroom use, individual articles and short works lawfully published in collections, newspapers, and other periodical publications or (brief) excerpts from lawfully published writ- 
ten works (some laws explicitly exclude computer programs).

- The provision is qualified in some laws by a provision that reproduction is permitted when there is no license for reproduction issued by the organization administering the property rights by collective management or when there are no restrictions on the part of collective management organizations concerning the terms and conditions for such reproduction.

It is clear that this provision was intended originally for reprographic reproduction of written works. The provision in the Armenian law (Article 15) is entitled "Use of a work by means of reprographic reproduction."

Azerbaijan, Russia (Article 20), and Uzbekistan (Article 29) add that indication also must be made of the work used in the reproduction. Kazakhstan (Article 20), Kyrgyzstan (Article 20), Russia, Tajikistan (Article 20[7]), Turkmenistan (Article 1086), Ukraine, and Uzbekistan (Article 29) add that the work reproduced may be with or without illustrations. The Azerbaijan provision adds the phrase that the reproduction may only be "to the extent necessary." Ukraine adds a phrase with respect to educational institutions that the extent of the reproduction must be justified by the purpose and adds a phrase with respect to both libraries and archives and educational institutions that the reproduction must be isolated and not systematic. Moldova indicates that the reproduction must be isolated and "to the extent justified by the intended purpose." Azerbaijan, Georgia, and Moldova include personal use as a justification for reproduction by libraries and archives for users.

Azerbaijan, Georgia (Article 22), and Moldova explicitly exclude computer programs from this provision, and Ukraine (Article 22) explicitly excludes computer programs and databases. In any case, all of the laws (as discussed below) have special provisions for the reproduction of computer programs. Belarus (Article 20) does not provide for reproduction by libraries and archives to provide copies to other libraries that have for any reason lost the work from their collections. The laws of Moldova, Ukraine, and Tajikistan add a phrase indicating that reproduction for other libraries and archives may be performed only if such reproduction is not possible by other means. Ukraine (Article 22) specifies that this provision applies only to libraries and archives, the activity of which is not aimed directly or indirectly at profit. Georgia has a similar qualification against either direct or indirect profit.

Azerbaijan (Article 18), Moldova (Article 21), and Ukraine (Articles 22 and 23) include a clause to the effect that reproduction is permitted only when there is no license for reproduction issued by the organization administering the property rights by collective management (or when there are no restrictions in the part of collective management organizations concerning the terms and conditions for such reproduction).

\section{Export of Works for Personal Use}

Two of the CIS laws, those of Kazakhstan (Article 27) and Moldova (Article 22(2)), contain a provision allowing for export of a work by an individual for personal use without consent of the author or other copyright holder or payment of remuneration. The Kazakh provision also includes a stipulation that such export of a work must not prejudice the national interests of the Republic of Kazakhstan. This provision is undoubtedly meant to address the restrictions set by nonvoluntary licenses against cross-border circulation of copyrighted works produced in one country under a nonvoluntary license 
into a country that does not provide for such licenses, as a trade issue. Because nonvoluntary licenses are effective only in the country that establishes them, rights for products containing copyrighted works are protected through the system of nonvoluntary licenses. Kazakhstan and Moldova are unique in specifying the possibility for exporting works for personal use.

\section{Computer Programs and Databases}

All of the CIS laws except Uzbekistan's include a provision stipulating the terms by which computer programs and databases may be reproduced, modified, studied, or tested and by which computer programs may be decompiled. In some of the laws, these are included in two separate articles. Several elements are included in these provisions, which are contained with some variation across the CIS laws:

- The use is permissible without consent of the author or other copyright holder and without payment of remuneration.

- The use is made from a lawfully acquired computer program or database.

- The reproduction or modification is to enable functionality or interoperability, including correction of mistakes; for archival purposes; or for replacement of a computer program or database that has become lost, damaged/destroyed, or unusable.

- The purpose for study or testing of a computer program is to determine the ideas and principles that form the basis of any element of the program; in some laws, this is subject to the condition that inspecting, studying, or modifying the functionality of a program is done in order to enable an action such as loading, display, functionality, transfer, or saving the program.

- The purpose for decompilation of a computer program is to enable interoperability with another computer program.
- Some laws specify that reproduction is restricted to one copy.

- Some laws specify that reproduction or modification is to the extent justified by the use of the program or database.

- Some laws add that modifications may be made only if not otherwise stipulated in agreement with the author.

- Further conditions apply for decompilation as stipulated in the individual laws.

This provision is contained in the laws of Armenia (Article 18), Azerbaijan (Article 24), Belarus (Article 21), Georgia (Articles 28 and 29), Kazakhstan (Article 24), Kyrgyzstan (Article 25), Moldova (Article 23), Russia (Article 25), Tajikistan (Article 24), Turkmenistan (Articles 1092 and 1093), and Ukraine (Article 24).

Only Armenia, Moldova, and Ukraine include the terms on study or testing of a computer program. The provision of Belarus deals only with reproduction of computer programs for archival or replacement purposes or modification of computer programs for interoperability; it does not include databases and the aspects of study or testing, or of decompilation. Moldova's 2002 amendment eliminated databases from the scope of Article 23, as well as permission to copy and save to the computer's memory and to retain a copy of a program for archival purposes. Azerbaijan, Georgia (Article 28), and Moldova stipulate that modifications may be made only when not otherwise stipulated in an agreement with the author.

Georgia (Article 29) and Turkmenistan (Article 1093) contain a separate article concerning decompilation of computer programs. The Georgian law includes an additional provision (Article 30) allowing for free use of a database without consent of the author or other copyright holder when it is necessary for investigation of 
the database and its normal use. Free use is restricted to those parts of a database that the user has lawful rights to use. Uzbekistan (Article 34) has not developed a full provision of this type. Article 34 states simply that the right of an individual in lawful possession of a copy of a computer program or database to reproduce or modify the program or database for personal use is determined by law.

\section{CIS Exceptions to Copyright Included in the Rome Convention}

It is worthwhile to add here that the International Convention for the Protection of Performers, Producers of Phonograms, and Broadcasting Organizations, known as the Rome Convention, which dates from 1961 and governs neighboring rights, also includes limitations and exceptions that serve as models for national laws and should be considered within the context of this discussion of free-use limitations and exceptions. As of January 2004, six CIS nations were members of the Rome Convention: Armenia, Belarus, Kyrgyzstan, Moldova, Russia, and Ukraine.

Article 15(1) contains four exceptions to the protection provided by the convention, in some respects echoing provisions in Berne:

- private use;

- use of short excerpts in connection with the reporting of current events;

- ephemeral fixation by a broadcasting organization by means of its own facilities and for its own broadcasts; and

- use solely for the purposes of teaching or scientific research.

These provisions are not qualified in any more detail and have been interpreted in more than one way. It is clear that the exception relating to current-events reporting resembles Article 10bis(1) of Berne and the exception regarding ephemeral recordings resembles Article 11bis(3) of
Berne, but the private-use exception does not derive from a Berne provision. It has been suggested that the fourth exception goes far beyond the scope of Article 10(2) of Berne, which, as mentioned, does not include the idea of scientific research. ${ }^{38}$

In addition, Article 15(2) of the Rome Convention allows member states to adopt in national legislation the same kinds of limitations with respect to neighboring rights as it provides for copyright in literary and artistic works. However, compulsory licenses "may be provided for only to the extent to which they are compatible with this Convention."

It is interesting that most of the CIS nations, regardless of whether they are parties to the Rome Convention, contain the exceptions outlined in Articles 15(1) and 15(2) of the Rome Convention, with some variation. In addition, they all add a clause allowing for use in quotation that is not explicit in the Rome Convention. There are several elements to the provisions across the laws:

- personal use of works, subject to payment of remuneration (some laws specify payment for phonograms, and others specify payment for other works covered under neighboring rights as well);

- use of excerpts (in some laws restricted to short excerpts) for reporting of current events, without consent of the right-holder and without payment of remuneration;

- ephemeral recordings by a broadcasting organization using its own equipment and for the purposes of its own broadcasts (this is generally a separate provision and is discussed above);

- use of a work for the exclusive purposes of teaching or scientific research, without consent of the right-holder and without payment of remuneration;

- quotation of excerpts (in some laws restricted to short excerpts) for informa- 
tional purposes, without consent of the right-holder and without payment of remuneration;

- use of literary, scientific, or artistic works in accordance with other limitations and exceptions in the respective laws, without consent of the right-holder and without payment of remuneration;

- further stipulation that the limitations to neighboring rights provided for in the provision do not prejudice either the normal exploitation of the phonogram, performance, or program, or the normal exploitation of the literary, scientific, or artistic work incorporated into it, and not prejudice the lawful interests of the right-holder or the author.

Such provisions generally are found in articles dealing with "limitations to the rights of performers, producers of sound recordings, and broadcasting or cable distribution organizations," or "free use of the objects of neighboring rights." They are in the laws of Armenia (Article 36), Azerbaijan (Articles 36 and 38), Belarus (Articles 36 and 37), Georgia (Articles 51 and 53), Kazakhstan (Article 41), Kyrgyzstan (Article 42), Moldova (Articles 30 and 32), Russia (Article 42), Tajikistan (Article 41), Turkmenistan (Articles 1120 and 1122), Ukraine (Article 42), and Uzbekistan (Article 60).

Azerbaijan, Georgia, Moldova, and Turkmenistan qualify the use for teaching as being that of illustration in teaching. Kazakhstan, Kyrgyzstan, Russia, Tajikistan, and Uzbekistan use the term "short excerpts" instead of "excerpts" with respect to use for quotation and reporting of current events. Georgia uses the term "short excerpts" instead of "excerpts" with respect to use for illustration in teaching and in scientific research and the reporting of current events. Azerbaijan, Moldova, and Turkmenistan use the term "short excerpts" with respect to use for quotation, illustration in teaching, and the reporting of current events. Azerbaijan, Georgia, Moldova, and Turkmenistan include a list of justified purposes for the use of quotation derived from Berne Article 10(1): scientific, research, polemical, critical, and informational use to the extent justified by the purpose of the quotation.

The Armenian provision is called a "limitation of the rights of a performer, producer of the first fixation of performances or audiovisual recordings, and of a broadcasting organization." It is shorter and constructed differently, stipulating that Articles 13, 14, and 17 of the law (governing free use of works, personal use of works, and free use of ephemeral recordings by a broadcasting organization) may be applied to the objects of neighboring rights without consent of the right-holder and without payment of remuneration, subject to the conditions of the three-step test.

Ukraine constructs this provision in a similar manner, stipulating that Articles 21 through 25 of the law (the provisions for free use of literary, scientific, and artistic works) may be applied to the objects of neighboring rights without consent of the right-holder and without payment of remuneration. Several conditions apply: that the reproduction is solely for the purpose of teaching or scientific research; that the use does not extend to materials exported from Ukraine; that right-holders retain the right to equitable remuneration for multiple copies of a work; and that the moral rights of right-holders are respected. Personal use is allowed without consent but is subject to payment of remuneration to the right-holder. The provision stipulates the conditions of the three-step test.

\section{Summary and Conclusions}

It seems appropriate to highlight the practical effects of the limitations and 
exceptions discussed in this analysis in order to understand how U.S. librarians can use the above information in everyday situations. This article has focused on provisions in CIS laws governing the use of copyrighted material within the territories of CIS nations. CIS nations apply their national laws to U.S. works being utilized on their territory in the same manner that they apply their laws to domestic works. The free-use provisions thus apply as they do to those nations' domestic works. Although some differences exist among CIS laws, the following general summary may serve to aid in synthesizing the information presented above.

Six limitations and exceptions discussed above exist for the purpose of freedom of information, including free use of official texts; they were largely created for the benefit of the press and broadcasting media and, more broadly, to benefit the public. A closely related exception concerning preservation of ephemeral broadcast recordings more narrowly benefits the press and broadcasting media. These limitations and exceptions all originate in the Berne Convention as mandatory or optional provisions for implementation in national laws. They all have been adopted in some form in the CIS.

- None of the CIS nations extends protection to official texts of a legislative, administrative, or legal nature. Nonetheless, it is important to note that not all government-produced works are of a legislative, administrative, or legal nature and that many different types of official publications are still protected in the CIS nations, such as government manuals, textbooks, reference works, and so on.

- None of the CIS nations extends protection to "news of the day." This limitation, created for the benefit of the press, allows for freedom in news reporting so that information can circulate in the news media. Nonetheless, it is important to note that original journalistic articles, insofar as they are original works, even when based on the same facts, are protected and do not fall under this limitation.

- Like news of the day, political speeches and speeches delivered during legal proceedings are treated in the Berne Convention as meriting exceptional treatment justified by freedom of information. CIS nations approach this limitation differently, but in all nations it applies solely to reproduction for the benefit of the press and broadcasting media. Azerbaijan, Georgia, and Turkmenistan allow free reproduction by the press of publicly delivered political speeches and speeches delivered during court proceedings. Other nations apply this limitation only to publicly delivered political speeches, addresses, and so on., but not to speeches delivered during legal proceedings. Still other nations (Belarus, Moldova, Tajikistan, and Ukraine) allow for reproduction by the press of publicly delivered speeches, addresses, and so on that are not necessarily political in content, while not allowing for the same concerning speeches delivered during legal proceedings. It is sufficient to note that this category of works is offered special treatment; details need to be reviewed in the laws themselves.

- All the CIS nations grant an exception allowing for reproduction and broadcasting of newspaper and periodical articles on current events. Notwithstanding minor differences in the definition of "current events," the exception, again, facilitates circulation of news information for the benefit of the press and the larger benefit of the public.

- Three nations-Belarus, Tajikistan, and Ukraine-grant an exception permitting reproduction and broadcasting by the press of publicly delivered speeches, addresses, and so forth on any subject. Moldova restricts this category to public speeches, addresses, and so forth on cur- 
rent topics. Therefore, a public lecture on the current status of women in the workplace, for example, could be used in the media to the extent justified by the purpose in Belarus, Tajikistan, or Ukraine, but it could not be used in the other CIS nations if not deemed "political" in content.

- For the purpose of reporting current events, all the CIS nations except Moldova allow for incidental reproduction of literary or artistic works seen or heard incidentally in the reporting of current events. For example, background music heard during a news interview or a copyrighted painting visible in the background of a televised public speech may be broadcast without infringing copyright.

- All of the CIS nations except Ukraine allow broadcasting organizations to make short-term, or ephemeral, recordings of broadcast works, and all of those except Moldova permit retention of such recordings in official archives when they are of an exceptional documentary character.

Two of the exceptions discussed in this study cast a wider benefit in making information available in accordance with fair practice and for use in teaching. Both are important to the missions of academic and research libraries and educational institutions.

- All of the CIS nations allow for quotation of works that are published or lawfully made available to the public within the limits of fair practice, for specified purposes (for the most part scientific, research, polemical, critical, and informational), providing that the source and the name of the author are identified. This provision makes possible the advancement of education and culture through scholarly writing, publishing, and criticism. The most important distinction in this provision concerns the requirement that the work already be published or made publicly available: unpublished works do not fall under this exception. It is not permissible under this provision to quote from an unpublished diary or any unpublished archival document that is still copyrighted.

- All of the CIS nations except Moldova allow for use of works that are published or lawfully made available to the public for the purpose of illustration in teaching, providing that the source and the name of the author are indicated. This provision concerns display or reproduction of published works in a teaching situation. Like the previous exception, it does not cover unpublished material. It does not cover reproduction of works for personal use, study, or research outside the classroom, such as for home assignments. It bears an ambiguous relationship to a further exception involving reproduction for classroom use, discussed below.

The remaining free-use exceptions found in CIS laws do not originate in the Berne Convention but, rather, are adopted in CIS national laws as a common practice. They can be categorized as exceptions that benefit individuals or society without harming the moral or economic rights of the author. Exceptions for the benefit of libraries and educational institutions are included here.

- All of the CIS nations allow for reproduction of published or lawfully disclosed work for personal use or for use of members of the family; usually this means one copy. It does not include certain types of material such as computer programs and databases, but some nations have separate provisions for personal use of computer programs and databases. This exception does not cover personal use of unpublished or undisclosed material. Furthermore, the use of audiovisual works and sound recordings for personal use in all countries except Armenia requires remuneration to holders of copyright and neighboring rights. 
- All the CIS nations contain an exception allowing performance of a lawfully disclosed musical work for official, religious, or ritual ceremonies such as state events and funerals. Unpublished musical works are not covered by this exception.

- All the CIS laws allow for reproduction of a work for judicial proceedings; all except Georgia, Russia, Tajikistan, and Turkmenistan also allow for such use for administrative proceedings.

- All the CIS laws except Ukraine's allow for the reproduction or broadcasting of architectural works, photographic works, and works of fine art that are permanently located in a public location, as an incidental use due to the immobility of these structures. This provision does not cover situations when the main purpose of the use is to reproduce or broadcast the image of such works or when the image is being used commercially.

- Ukraine has a unique exception allowing reproduction in exhibition or sales catalogs of photographs or artistic works open to the public.

- All the CIS laws contain an exception for reproduction of published or lawfully disclosed works for the blind, such as in Braille, providing the author and the source are indicated. This exception does not cover unpublished or undisclosed works.

- All the CIS laws contain an exception for libraries and archives permitting reproduction of one copy of a lawfully published or disclosed work for purposes of preservation or replacement, in most cases for other libraries as well; or to provide copies of individual articles, short works, or brief excerpts of a published work to individuals upon request for study, educational, or research use, and, in some cases, personal use. This exception also permits educational institutions to reproduce, for classroom use, individual articles, short works, and brief excerpts of lawfully published works. This exception does not cover unpublished or undisclosed material; it involves only the right of reproduction. None of the CIS laws yet clearly deals with use of digital material in this context, but the absence of any exception for the right of public display or distribution indicates that they deal with digital preservation and lending in a way similar to the United States, allowing for digital reproduction, but not public display or distribution of the digital works.

- Kazakhstan and Moldova allow for export of a work by an individual to another country for personal use. This somewhat unusual provision is a way of protecting individuals from restrictions involving cross-border circulation of copyrighted works-sound recordings and films, for example-if they are traveling with lawful personal copies of such works.

- All the CIS laws except Uzbekistan's allow for some form of reproduction, modification, study, or testing of computer programs and databases and for decompilation of computer programs. This exception exists mainly for the purpose of enabling functionality or interoperability, archiving, or replacement. Only Armenia, Moldova, and Ukraine allow for study or testing of computer programs. Belarus and Moldova do not include databases within the scope of this provision.

Most of the CIS nations include in their national laws the four exceptions set out in the Rome Convention governing the rights of performers, producers of phonograms, and broadcast organizations, whether or not they are adherents to this convention. They also allow for use in quotation, an exception not stated in the Rome Convention. From a practical standpoint, these exceptions are relevant to librarians only when they are handling audiovisual works, sound recordings, broadcasts, and other nonprint formats that are the objects of neighboring rights. 
- Nearly all of the CIS nations grant clear exceptions for personal or private use, subject to remuneration; use in current-events reporting; ephemeral fixation of broadcasts by broadcasting organizations; use in teaching or scientific research; and quotation of excerpts. Thus, for example, in most of these nations it is possible to play excerpts of a sound recording in reporting current events without payment of remuneration, but personal use of the sound recording requires payment to the author of the sound recording.

- All the CIS nations except Georgia include an open-ended clause allowing for further use of objects of neighboring rights in accordance with other limitations and exceptions specified in the copyright laws.

Several conclusions may be drawn from this analysis of the current copyright laws of the CIS nations. It is clear that these twelve nations fully recognize the social importance of limitations and exceptions to copyright for the library and educational communities, as well as for organizations and individuals engaged in free and culturally productive exchange of information and ideas. From the range of possible limitations and exceptions in the Berne Convention and from among those commonly present in copyright laws worldwide, the CIS nations have adopted generous exceptions to the rights of authors and copyright holders. Even though copyright laws in the CIS nations, as in most nations, are subject to frequent amendment, this snapshot illustrates the statutory basis for copyright limitations and exceptions in those nations today.

The numerous exceptions to the rights of authors and copyright holders closely follow the language and structure of the Berne Convention, and the laws include many additional exceptions, reflecting a common approach to broad limitations to copyright. In this respect, it can be said that the laws are closely modeled after Berne, and where the Berne provisions leave off, the CIS laws closely follow one another. Questions of application and enforcement of the statutes are, of course, a different matter and for a separate discussion, as are questions of infringement of intellectual property law.

U.S. librarians need to be aware of how U.S. materials may used abroad out of concern for authors whose works are used by foreign library users and who may approach them with questions about international copyright with this in mind. In working with foreign colleagues, or with anyone who uses U.S. material in foreign countries, it is useful to know the limits of library, educational, and other uses of foreign material in those countries. This becomes particularly important as libraries create more original digital content and educational institutions adopt scholarly publishing models based on electronic delivery, which facilitates easy use abroad. Furthermore, and not of least importance, there is a need to have a basic comparative understanding of free- and fair-use provisions in order to be conversant about the continued role of copyright limitations and exceptions in the digital age.

The dimensions of recent developments in copyright are vast. The digital age, which started off as one of increased access to information, in some respects has become one of increasing restriction, as the laws that brought copyright principles into the information age are now being used to limit the use of works. It is important to remember that technology has always been a force for change in copyright law, but also to be mindful, in the continuum of change, not to lose sight of the responsibility that lawmakers and librarians share as curators of the intellectual and creative endeavors of nations to ensure that the free exchange of knowledge and information remains a feature of modern civilization. 
It is heartening to see that the copyright laws of the CIS nations reflect a commitment to the humanistic ideals inherent in societies that acknowledge the value and power of knowledge, learning, and the free exchange of information.

\section{Notes}

1. Folsom v Marsh, 9 F. Cas. 342, 348 (C.C.D. Mass. 1841).

2. Lawrence $v$ Dana, 15 F. Cas. 26 (C.C.D. Mass. 1869).

3. The "Gentleman's Agreement" is reprinted in Leon E. Seltzer, Exemptions and Fair Use in Copyright, appendix E (Cambridge, Mass.: Harvard Univ. Pr., 1978), 192-93.

4. See, for example, Gerald Dworkin, "Exceptions to Copyright Exclusivity: Is Fair Use Consistent with Article 9.2 Berne and the New International Order," chapter 66 in International Intellectual Property Law E Policy, ed. Hugh C. Hansen (Yonkers, N.Y.: Juris Pub.; London, Sweet \& Maxwell, 2000), 66-6.

5. The current copyright laws of the CIS nations are as follows:

- Law of the Republic of Armenia on Copyright and Neighboring Rights No. HO-28, adopted on Dec. 8, 1999 (dated Jan. 12, 2000); with Amendment No. HO-269, adopted on Dec. 4, 2001 (dated Dec. 24, 2001); Amendment No. 416-N, adopted on Sept. 25, 2002 (dated Oct. 21, 2002); and Amendment No. HO-449-N, adopted on Nov. 20, 2002 (dated Nov. 28, 2002).

- Law of the Republic of Azerbaijan on Copyright and Neighboring Rights No. 115-1G, dated June 5, 1996.

- Law of the Republic of Belarus on Copyright and Neighboring Rights, No. 194-3, dated Aug. 11, 1998.

- Law of Georgia on Author's and Neighboring Rights No. 2112-IIc, dated June 22, 1999; as amended by the Law of Georgia on Introduction of Additions to the Law of Georgia on Copyright and Neighboring Rights No. 2388-Ic, dated Sept. 9, 1999; and the Law of Georgia on Introduction of Amendments to the Law of Georgia on Copyright and Neighboring Rights No. 651-Ic, dated Dec. 5, 2000.

- Law of the Republic of Kazakhstan on Copyright and Neighboring Rights No. 6-1, dated June 10, 1996.

- Law of the Republic of Kyrgyzstan on Copyright and Neighboring Rights, dated Jan. 14, 1998; as amended by the Law of the Republic of Kyrgyzstan on Introduction of Amendments and Additions to the Law of the Republic of Kyrgyzstan on Copyright and Neighboring Rights No. 120, dated Nov. 6, 1999.

- Law of the Republic of Moldova on Copyright and Neighboring Rights No. 293-XIII, dated Nov. 23, 1994; as amended by the Law on Amendments and Additions to the Law on Copyright and Neighboring Rights No. 29-XIV, dated May 28, 1998; the Law on Introduction of Additions to the Law on Copyright and Neighboring Rights No. 1207-XIV, dated July 28, 2000; and the Law on Introduction of Amendments and Additions to the Law on Copyright and Neighboring Rights No. 293-XIII of Nov. 23, 1994, No. 1268-XV, dated July 25, 2002.

- Law of the Russian Federation on Copyright and Neighboring Rights No. 5351-1, dated July 9, 1993, as amended by Federal Law No. 110-FZ, on the Introduction of Amendments and Additions to the Code of Criminal Procedure of the RSFSR, the Code of the RSFSR on Administrative Offenses and the Law of the Russian Federation on Copyright and Neighboring Rights, dated July 19, 1995.

- Law of the Republic of Tajikistan on Copyright and Neighboring Rights No. 726, dated Nov. 13, 1998.

- Turkmenistan Civil Code of Saparmurat Turkmenbashi, Part 4, Sections 1-5, adopted July 17, 1998. The text used as the basis for this analysis was Turkmenistan Civil Code of Saparmurat Turkmenbashi, edited and translated by William E. Butler (The Hague: Kluwer Law International; London: Simmonds \& Hill, 1999).

- Law of Ukraine on Copyright and Neighboring Rights No. 3792-12, dated Dec. 23, 1993; as amended by the Law of Ukraine No. 75/95-VR of Feb. 28, 1995; Law No. 998-XIV of July 16, 1999; Law No. 2627-III of July 11, 2001; and Law of Ukraine on Introduction of Amendments to the Law of Ukraine on Copyright and Neighboring Rights No. 2627-III, dated July 11, 2001, which constitutes a major revision, with new wording, and replaces the previous law.

- Law of the Republic of Uzbekistan on Copyright and Neighboring Rights No. 272-I, dated Aug. 30, 1996; as amended by Law No. 175-II, dated Dec. 15, 2000.

6. For an understanding of the main issues surrounding copyright for Slavic, East European, and Eurasian materials in the United States and a method for approaching questions related to copyright, see Janice T. Pilch, "Understanding Copyright Law for Slavic, East European, and Eurasian Materials," Slavic and East European Information Resources 4, no. 1 (2003): 75-101; - 
"International Copyright for Digital Collections of Russian Material: U.S. and U.K Law and Practice," Solanus: International Journal for Russian E East European Bibliographic, Library E Publishing Studies 17 (2003): 24-49. A three-part series of articles by this author on the laws of the CIS nations is forthcoming in the journal Slavic and East European Information Resources, beginning with "Current Copyright Legislation of the CIS Nations and Its Relevance for U.S. Library Collections: The Laws of Russia, Ukraine, Belarus, and Moldova," Slavic and East European Information Resources 5, no. 1-2 (2004): 81-122.

7. World Intellectual Property Organization, WIPO Glossary of Terms of the Law of Copyright and Neighboring Rights (Geneva: World Intellectual Property Organization, 1980), 125.

8. The WIPO Guide to the Berne Convention for the Protection of Literary and Artistic Works (Paris Act, 1971) explains that the concept of fair practice was introduced at the Stockholm Revision of Berne in 1967. "It implies an objective appreciation of what is normally considered admissible. The fairness or otherwise of what is done is ultimately a matter for the courts, who will no doubt consider such questions as the size of the extract in proportion both to the work from which it was taken and that in which it is used, and, particularly the extent to which, if any, the new work, by competing with the old, cuts in upon its sales, circulation, etc." World Intellectual Property Organization, Guide to the Berne Convention for the Protection of Literary and Artistic Works (Paris Act, 1971)(Geneva: World Intellectual Property Organization, 1978), 58-59.

9. House Committee Report on the 1976 Copyright Bill (House Committee on the Judiciary, House Report No. 94-1476, to accompany S. 22, 94 ${ }^{\text {th }}$ Cong., 2d Sess., Sept. 3, 1976), 66.

10. Tyler G. Newby, "What's Fair Here Is Not Fair Everywhere: Does the American Fair Use Doctrine Violate International Copyright Law?" Stanford Law Review 51 (July 1999): 1637.

11. William C. Walker Jr., "Fair Use: The Adjustable Tool for Maintaining Copyright Equilibrium," Louisiana Law Review 43, no. 3 (Jan. 1983): 735-57.

12. Lloyd L. Weinreb, "Fair Use," Fordham Law Review 67, no. 4 (Mar. 1999): 1298-99 (footnote omitted). The fourteen categorical exemptions to which reference is made have increased to fifteen since the publication of Professor Weinreb's article.

13. Eric Allen Engle, "When Is Fair Use Fair? A Comparison of E.U. and U.S. Intellectual Property Law," Transnational Lawyer 15 (spring 2002): 225.

14. WIPO Glossary of Terms, 147.

15. Stephen M. Stewart, International Copyright and Neighboring Rights, 2d ed. (London: Butterworths, 1989), 79-81.

16. Paul Goldstein, International Copyright: Principles, Law and Practice (Oxford: Oxford Univ. Pr., 2001), 292-315.

17. J. A. L. Sterling, World Copyright Law: Protection of Authors' Works, Performances, Phonograms, Films, Video, Broadcasts and Published Editions in National, International and Regional Law (London: Sweet \& Maxwell, 1998), 351-54.

18. Ibid., 358.

19. World Intellectual Property Organization, Standing Committee on Copyright and Related Rights, Ninth Session, WIPO Study on Limitations and Exceptions of Copyright and Related Rights in the Digital Environment, prepared by Sam Ricketson, SCCR/9/7 (Geneva: 2003), 3-4.

20. WIPO, Guide to the Berne Convention for the Protection of Literary and Artistic Works, 20.

21. Ibid., 23. WIPO defines news of the day as: "[m]ere information on recent events or facts by the press, broadcasting or other appropriate means. It is not a work eligible for copyright protection." WIPO Glossary of Terms of the Law of Copyright and Neighboring Rights, 169.

22. Ricketson, WIPO Study on Limitations and Exceptions of Copyright and Related Rights in the Digital Environment, 10-11.

23. WIPO, Guide to the Berne Convention for the Protection of Literary and Artistic Works, 24.

24. Ricketson, WIPO Study on Limitations and Exceptions of Copyright and Related Rights in the Digital Environment, 13.

25. An author's page is defined as a unit of measure of the volume of a work upon its publication. It generally consists of 40,000 printed signs (letters, punctuation marks, numerals, etc., and also spaces between words). An author's page amounts roughly to 700 lines of a written work or 3,000 cubic centimeters of a graphic work. See Dreptul de Autor şi Drepturile Conexe: Culegere (Chişinău, 1997), 110, 254.

26. Ricketson, WIPO Study on Limitations and Exceptions of Copyright and Related Rights in the Digital Environment, 13-14.

27. WIPO, Guide to the Berne Convention for the Protection of Literary and Artistic Works, 59.

28. Ibid., 59.

29. Ibid., 60 .

30. Ricketson, WIPO Study on Limitations and Exceptions of Copyright and Related Rights in the Digital Environment, 15.

31. WIPO, Guide to the Berne Convention for the Protection of Literary and Artistic Works, 60. 
32. Ibid., 73.

33. There is a terminological distinction between personal use and private use. Personal use is generally understood to be the making of a single reproduction or a transformation of the work, such as a translation, adaptation, or arrangement, for the exclusive use of the individual making the copy. Private use has a broader scope, involving the making of a reproduction or a transformation of a work, in a single copy or several copies, that may serve not only the exclusive use of the individual making the copy but also be shared by a specific group of persons, such as family members and close friends, and used by a legal entity; such copies must not be made available to the public. Both personal and private uses generally fall under the category of free uses. See WIPO Glossary of Terms of the Law of Copyright and Neighboring Rights, 185, 198. See also Delia Lipszyc, Copyright and Neighboring Rights (Paris, Unesco, 1999), 226-27.

34. The private copying levy is common in national copyright laws as a way of protecting the economic interests of copyright holders (authors, publishers, producers of sound recordings and audiovisual works, performing artists, etc.). The levy is not directly linked to specific copyright holders or to those making private copies but, rather, is incorporated into a system involving a general fund for copyright holders. The responsibility for payment lies not with the individuals making private copies but, instead, with the manufacturers and importers of equipment and materials used for the purpose of reproduction. Professor Lipszyc elucidates: "This payment, then, is not for the actual use but for the possibility that such equipment offers of making copies." Lipszyc, Copyright and Neighboring Rights, 245-48.

35. Ricketson, WIPO Study on Limitations and Exceptions of Copyright and Related Rights in the Digital Environment, 34-7.

36. Professor Lipszyc writes that this exception is recognized in some laws with respect to free use of musical works by musical bodies belonging to the state. See Lipszyc, Copyright and Neighboring Rights, 241.

The CIS laws, on the other hand, do not include any specification that the music must be performed by state-affiliated bodies.

37. Reference to this limitation is made in Lipszyc, Copyright and Neighboring Rights, 241.

38. Ricketson, WIPO Study on Limitations and Exceptions of Copyright and Related Rights in the Digital Environment, 45. 